\title{
Review on Proteomics for Food Authentication*
}

\author{
Ignacio Ortea, Gavin O’Connor, and Alain Maquet
}

\section{CONTENTS}

1.1 Introduction 3

1.2 Proteomics 4

1.2.1 General Areas 4

1.2.2 Proteomic Workflows 6

1.2.3 Sample Preparation 7

1.2.4 Gel-Based or MS-Based Approaches 9

$\begin{array}{ll}1.2 .5 \text { Foodomics } & 10\end{array}$

1.3 Applications in Food Authentication $\quad 10$

1.3.1 Milk and Dairy Products 14

$\begin{array}{ll}\text { 1.3.2 Meat } & 16\end{array}$

$\begin{array}{lll}1.3 .3 \text { Shellfish } & 17\end{array}$

$\begin{array}{lll}1.3 .4 & \text { Fish } & 20\end{array}$

$\begin{array}{ll}1.3 .5 \text { Wine } & 21\end{array}$

$\begin{array}{ll}\text { 1.3.6 GMOs } & 23\end{array}$

$\begin{array}{ll}\text { 1.3.7 Other Foodstuffs } & 24\end{array}$

$\begin{array}{lll}1.4 & \text { Future Trends } & 24\end{array}$

References $\quad 25$

\subsection{INTRODUCTION}

Consumers have a right to know what is in the food they are consuming and producers have a duty to inform and not knowingly mislead consumers as to the source or content of food products. Nevertheless, due to the increasing demand for food and the increased globalization of trade, there is a higher risk of adulteration occurring throughout the food chain. Food products can be deliberately substituted, partially or entirely, with similar, lower quality, and cheaper counterparts or unintentional errors can cause inadvertent mislabeling of products [1]. In both cases, such commercial fraud affects not only the consumers but also the food industry. Examples of common frauds are replacing key ingredients with cheaper alternatives, mislabeling animal species used in a food product,

\footnotetext{
* Originally published in Journal of Proteomics 147 (2016) 212-225
} 
incorrectly labeling ingredient proportions, selling aquaculture fish as wild-caught, and labeling ordinary foods as organic.

The adulteration of food products is a major concern not only for preventing economic fraud, but also for safety reasons. The non-declared introduction of food ingredients such as toxic or allergenic products may be harmful to consumer's health, thus representing a potential public health risk [2]. Moreover, mislabeling may affect the eating habits of certain groups of consumers, such as abstinence on religious grounds or specific lifestyle choices such as vegetarianism. In order to fight against adulteration and the misbranding of food products, many regulations are currently enforced [3-9], outlining the requirement for complete and truthful information about food products that are being traded.

For all these reasons, the authentication of food labeling claims must be guaranteed; therefore, accurate and reliable analytical methods are needed in order to verify that the components used in a food product are of the nature or quality demanded by the purchaser and compatible with the declaration of the seller. Many different instrumental techniques have been proposed for food authentication, such as high-performance liquid chromatography (HPLC), trace element analysis, stable isotope ratio (SIR) analysis, nuclear magnetic resonance (NMR) spectroscopy, and more recently, genomics, metabolomics, and proteomics approaches [10-12].

Proteomics is defined as the large-scale analysis of proteins in a particular biological system at a particular time [13]. The proteome, the total protein content of one particular biological system, is highly dynamic and is constantly changing according to different stimuli. Proteomics includes not only the structural and functional knowledge of proteins, but also the quantification of their abundance, the study of their modifications, the interactions between them, and the study of their localization. Proteomics, a discipline that up to a few years ago was only used in biomedical research, is currently being revealed as a powerful tool in food science research. During the many stages of food production, proteins can act as ideal indicators for many properties associated with food quality, composition, and origin. Proteome analysis can be applied in the systematic search for new marker proteins/peptides, thereby accelerating the development of assays to detect adulteration and deceptive practices. Subsequently, accurate and reliable analytical methodologies can be developed and validated to detect the previously identified marker proteins/peptides.

This review is a comprehensive and updated overview of the application, drawbacks, advantages, and challenges that both a global and a specific study of proteins for authentication using proteomics approaches can offer as a tool to comply with food labeling regulations and policies. Additionally, we describe the updated workflows, technologies, and tools that are being assessed in proteomics-related studies, and review the specific applications regarding food authenticity and, in some instances, food quality.

\subsection{PROTEOMICS}

\subsubsection{General Areas}

Depending on the general objective, most proteomic studies can be divided into three different areas:

(a) Qualitative Proteomics: Protein Characterization and Identification

The goal of qualitative proteomics is to identify and characterize the complete set of proteins present in a sample, which can include the characterization of the 
protein post-translational modifications (PTMs). This systematic investigation can focus on a complete proteome (e.g., all the proteins in a food product) or on a specific subset of the proteins (e.g., sarcoplasmic proteins, gluten proteins, glycosylated proteins). The two most common approaches for protein identification are peptide mass fingerprinting (PMF) [14] and peptide fragmentation fingerprinting (PFF) [15], both requiring enzymatic digestion of the studied proteins. Alternatively, tandem mass spectrometry (MS/MS) data from the intact protein can be used in a similar way, in an approach known as top-down proteomics [16]. All these approaches require the presence of the sequence information of the corresponding protein or a homologous one, in the database. The vast array of different animal and plant species used in the food industry is likely to result in the absence of many peptides/proteins in the current databases. This combined with the many different ingredients in food makes food proteomics a challenging subject. Great caution and extra scrutiny are often required even when working with simple foods. PTMs play a crucial role as they affect protein activity and stability. PTMs can occur due to a wide range of biological signals, as well as due to food processing methods including cooking and preservation treatments. More than 300 different types of PTMs are known, although only a few are being extensively investigated, such as phosphorylation, acetylation, glycosylation, and oxidation [17]. During food processing and storage, non-biological (environmental or process-induced) PTMs, termed non-enzymatic PTMs (nePTMs), such as carbonylation, thiol oxidation, aromatic hydroxylation, Maillard glycation, condensation, elimination of side chains, and peptide backbone breakdown, regularly occur $[18,19]$.

(b) Differential/Quantitative Proteomics

In food proteomes, the relative amount of proteins can change due mainly to foodstuff composition, the technological processing of the food, and the biological variability of the food components. Quantitative information at the protein level, such as the relative abundance of a specific protein between different samples, or the absolute amount of the protein, can be very helpful when looking for differences between different conditions (e.g., different technological treatments of food products; genetically modified [GM] vs non-GM food). Relative quantification can be achieved with different methodologies, which can be classified as gel-based, label-based, and label-free approaches [20]. Gel-based methods consist of the separation of proteins by two-dimensional electrophoresis (2-DE) and the comparison of protein abundance determined as the spot volume between different samples. Each sample being compared can be run on a different gel or, alternatively, up to three samples can be differentially labeled and run on the same gel using the difference gel electrophoresis (DIGE) technology [21], increasing confidence in the detection and quantification of differences in protein abundance. In the label-based methods, proteins or peptides are previously labeled using a mass tag and relative quantification is then obtained from the MS or MS/MS read-outs. In label-free approaches, protein amount is generally calculated based on the MS-extracted ion current signal of the peptides/proteins during a liquid chromatography (LC) run. Quantitative proteomic methodologies have been greatly improved with the introduction of selected reaction monitoring experiments (SRM), a highly sensitive LC-MS/MS acquisition mode that is commonly used in biomedicine research to verify and validate candidate biomarker proteins [22]. 
(c) Functional Proteomics

Functional proteomics studies the functional interaction between proteins, or between a protein and other molecules, and the consequences of these interactions [23]. The understanding of protein-protein interactions, through network analysis, will be crucial if further improvements in food quality are to be realized. Activity-based proteomics is another area related to functional proteomics, studying the specific activities of the proteins in a sample, such as function and inhibition [24]. MS imaging, a new imaging mode that allows mapping proteins within a tissue or sample section $[25,26]$, has proved to be a relevant tool for functional proteomics, since the location of the different protein isoforms can help to understand their roles.

\subsubsection{Proteomic Workflows}

As stated above, the analysis of a proteome is commonly performed after preparation of the sample, by one or more separation steps followed by mass spectrometric analysis. The great diversity and high dynamic range of proteins in food-related samples present a great challenge for MS analysis. For this reason, sample preparation usually includes enrichment of the proteins of interest. Common protocols when working with complex samples usually include depletion of the most abundant interfering proteins, selective enrichment of the low abundance proteins of interest, or even partial purification of the target proteins [27]. Before the final analysis in the mass spectrometer, further separation is performed at the protein and/or peptide level, typically based on gel electrophoresis (gel-based approach) and/or LC (gel-free approach). Depending on whether the MS analysis is carried out on the intact proteins or on the corresponding peptide fragments, two different proteomic workflows can be followed, namely, top-down and bottom-up, respectively. Figure 1.1 summarizes the most significant proteomic workflows used in food authentication.

In the bottom-up approach, proteins are enzymatically digested, commonly using trypsin, and the resulting peptides are analyzed by mass spectrometry [13]. Thus, this approach is sometimes known as peptide-based proteomics. Bottom-up approaches can be divided into two groups depending on whether the fractionation step, for reducing sample complexity, is performed at the protein level or at the peptide level, i.e., before or after the enzymatic digestion of the proteins. The first strategy is most commonly used in the two-dimensional electrophoresis gel-based approach, where proteins are isolated based on isoelectric point $(\mathrm{pI})$ or molecular weight $(\mathrm{Mw})$, so that they can be individually excised from the gel and digested into peptides. These peptides are then analyzed by MS for protein identification. In the latter approach, referred to as "shotgun" proteomics, the protein mixture is enzymatically digested without previous fractionation and the resulting mixture of peptides is separated by high-throughput LC, typically reversed-phase (RP) HPLC or ultra-high-performance liquid chromatography (UHPLC). Subsequently, the eluted peptides are analyzed using MS, which is usually coupled online with the LC system. However, depending on the complexity of the peptide mixtures, multidimensional liquid chromatography is sometimes needed to increase the resolving power of the chromatographic separation. Strong cation exchange (SCX) columns coupled with RP LC are the most common combination used.

The alternative approach, top-down proteomics [16], characterizes the fragments produced by the dissociation of the intact proteins directly inside the mass spectrometer, 


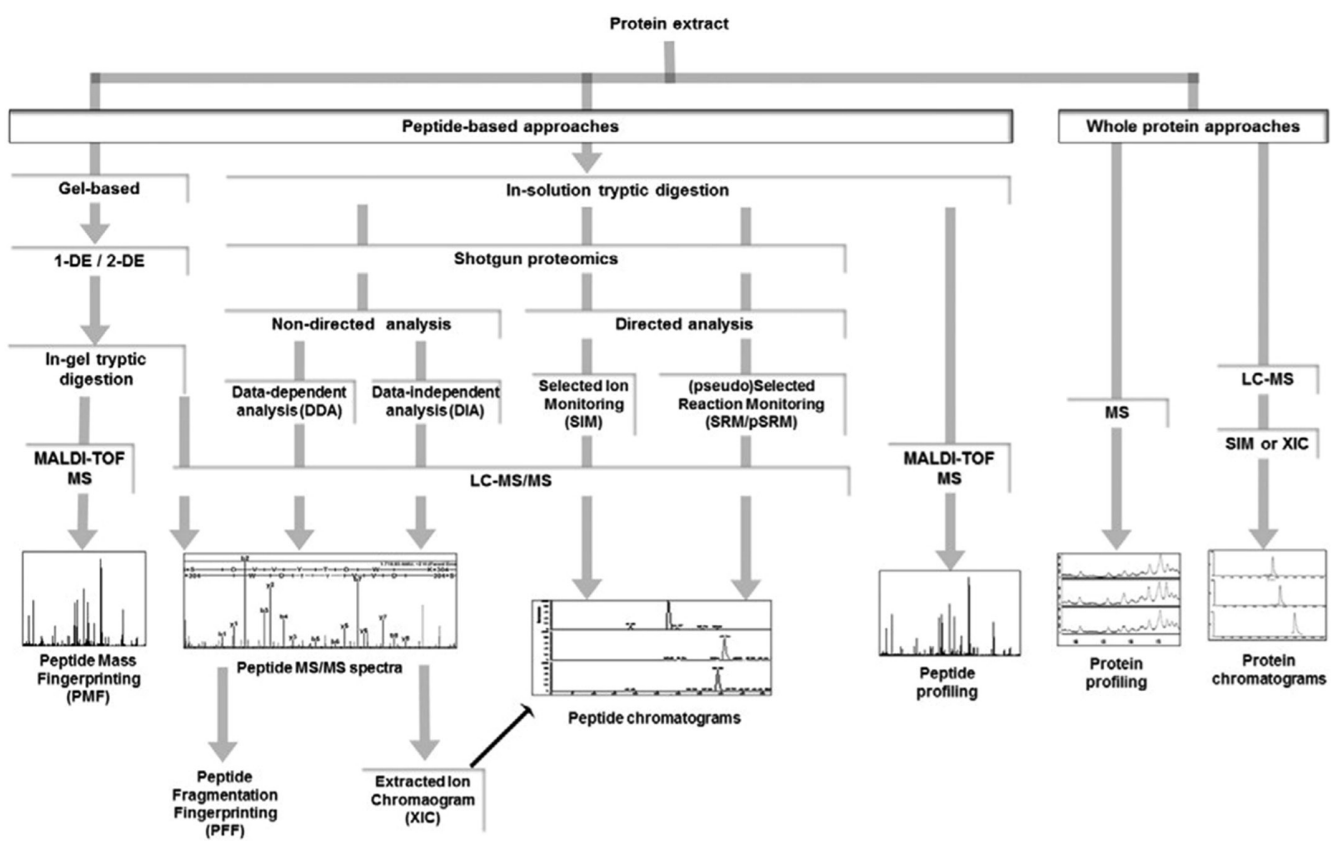

FIGURE 1.1 Common proteomic workflows used in food authentication.

avoiding the variable step of protein digestion. Although this kind of intact protein analysis is currently available due to new dissociation mechanisms and the high mass accuracy obtained in the new high-resolution MS equipment, its use is still limited due to instrumental constraints.

Although no common guidelines have been established for describing how to perform proteomics-related experiments, the Human Proteome Organization Proteomics Standards Initiative (HUPO-PSI; www.psidev.info) has developed guidance documents specifying the data and metadata that should be collected from several proteomics workflows, known collectively as the "minimum information about a proteomics experiment" (MIAPE) guidelines [28], in order to facilitate data comparison, exchange, and verification. MIAPEs include modules related not only to LC parameters and how MS data is generated, but also to study design, sample generation and preparation, and statistical analysis of data [29]. Although not mandatory, there is an increasing trend to follow these guidelines when publishing proteomics experiments in specialized proteomics journals. However, this is not always the case in journals from other areas such as food science and technology.

\subsubsection{Sample Preparation}

Protein extraction is a key step in a proteomic analysis. A specific protocol has to be optimized for each food sample, in order to maximize protein recovery and minimize proteolysis and modifications. Thus, there is no universal extraction buffer composition that can be used. Compounds for stabilizing and solubilizing proteins, such as $\mathrm{pH}$ regulators (e.g., tris[hydroxymethyl]aminomethane [Tris], 4-[2-hydroxyethyl]-1-piperazin eethanesulfonic acid [Hepes], 3-[N-morpholino]propanesulfonic acid [MOPS]), reducing 
agents (e.g., dithiothreitol, 2-mercaptoethanol), and denaturing compounds (e.g., $8 \mathrm{M}$ urea, sodium dodecyl sulfate [SDS], 3-cholamidopropyl dimethylammonio 1-propanesulfonate [CHAPS]) and for the elimination of contaminants such as nucleic acids (e.g., DNases), are added to the extraction buffer. The use of protease inhibitors, such as phenylmethanesulfonyl fluoride (PMSF) or ethylenediaminetetraacetic acid (EDTA), is strongly recommended. Most of the buffers used for protein extraction contain compounds that are not fully compatible with MS and thus a subsequent cleaning is required. However, a large number of the conventional protein extraction buffers are compatible with electrophoretic detection approaches. The best extraction method has to be experimentally determined for each type of sample and different mechanisms are available that can be used alone or in combination: organic solvents or detergents; enzymatic extraction; liquid nitrogen; mechanical disruption (e.g., use of ULTRATURRAX ${ }^{\circledR}$, blenders, manual grinding with mortar and pestle, Ballotini beads); sonication; and compression/ expansion. The method must be compatible with the subsequent measurement method, and also with the amount of material that is going to be processed. If measurements are not being performed immediately, protein samples should be stored in a manner that minimizes proteolysis and protein aggregation and modification; freezing in liquid nitrogen $\left(-196^{\circ} \mathrm{C}\right)$ or at $-80^{\circ} \mathrm{C}$ is recommended.

Sample purification can commonly include one or several of the following processes [27]: (1) procedures for clarifying and concentrating proteins, such as protein precipitation (e.g., ammonium sulfate, trichloroacetic [TCA]/acetone, chloroform), centrifugation, filtration (e.g., dialysis, ultrafiltration), and lyophilization; (2) procedures for enrichment, depletion, or fractionation: for reducing sample complexity and increasing the proportion of the target proteins. Chromatography (e.g., RP; SCX; size-exclusion chromatography [SEC]) and polyacrylamide gel electrophoresis (PAGE) (1-DE or 2-DE) are the most commonly applied fractionation techniques; off-gel isoelectric focusing, ultracentrifugation, and phase partitioning are also used. For the depletion of high-abundance proteins, or the enrichment of interesting ones, commercial immunoaffinity depletion kits are available, although these are generally for the removal of albumin and other human plasma proteins, thereby reflecting the difficulty faced in food proteomics in comparison to clinical proteomics in terms of method development. In this sense, the use of bead-based combinatorial peptide ligand libraries (CPLL) such as ProteoMiner has worked well in compressing the dynamic range of protein concentration in food samples [30-33]. Since the use of CPLL enhances the signal of trace components by up to four orders of magnitude, it represents a useful tool for studying matrices with very low concentrations of proteins, such as commercial beverages [34,35]. Depletion and fractionation procedures offer significant potential for improving the overall sensitivity of MS analysis; however, these strategies suffer from the limitations of low sample throughput since the fractions obtained have to be measured individually, and potentially poor sample recovery, due to non-specific binding of the target proteins to the antibody columns used for depletion or to high-abundance proteins (e.g., albumin), can lead to a partial or total loss of the analytes and to an underestimation of protein concentration [36].

A critical step in bottom-up proteomics is protein digestion, which is performed after electrophoresis isolation of the protein ("in-gel" digestion) for gel-based approaches, or directly on the protein mixture without previous fractionation ("in-solution" digestion). Many proteolytic enzymes can be used for protein digestion, although trypsin offers some advantages, as it mainly yields peptides of optimum amino acid composition, charge state, and homogeneous fragmentation by collision-induced dissociation (CID) 
for MS analysis due to its cleavage specificity, and for these reasons is the most commonly used protease. Since typical digestion times range from 6 to $24 \mathrm{~h}$, protein digestion is the most time-consuming step in the proteomic workflow. To accelerate protein digestion, and also to try to increase digestion efficiency, alternatives to the standard protocols have been proposed, such as the use of microwaves, infrared radiation, high-intensity focused ultrasounds, modified trypsin, and immobilized trypsin (e.g., in columns or nanoparticles) $[37,38]$.

\subsubsection{Gel-Based or MS-Based Approaches}

Although nowadays there is a general tendency within the proteomics community to move to gel-free workflows, the fact remains that electrophoresis has been extensively used and continues to be used in food authentication studies. Since data provided by protein electrophoresis is often complementary to data obtained from LC-MS-based approaches, we consider that protein electrophoresis, mainly 2-DE, still has a role in food-related studies.

SDS-PAGE, IEF, and 2-DE protein electrophoretic patterns have been extensively used in the development of methods aimed at the detection and authentication of the species present in food products [11], and IEF is the only officially validated method for species identification according to the Association of Official Analytical Chemists (AOAC, 1995).

However, electrophoretic methodologies for food authentication show some limitations, such as the analysis of hydrophobic and poorly soluble proteins, the limited dynamic range of the available detection methods, high complexity, and the dynamic range of the proteins in the sample, the degradation of proteins due to food processing, closely related species not well resolved, misidentification when analyzing samples with a mixture of several species, or the need for reference samples. For these reasons, food authentication methods using MS have recently gained much attention.

MS is the most common method of choice for the high-throughput identification, characterization, and quantification of proteins, allowing the analysis of thousands of proteins in one experiment. From the analysis of the mass spectra obtained, information about the peptide sequence and abundance can be obtained by applying a great variety of bioinformatic tools.

One important factor when deciding how to perform the analysis in the mass spectrometer is the method used for the acquisition of the MS/MS data, depending on the nature and the stage of the research. The approach known as data-dependent analysis (DDA) is the most popular acquisition mode when the objective is to analyze the highest possible number of proteins present in the sample. However, detected peptides are biased toward those coming from the highest-abundance proteins. To avoid this, the data-independent analysis (DIA) acquisition mode can be used. In this mode, instead of selecting one specific ion for fragmentation, all peptide ions present in the mass analyzer are fragmented. This approach is currently growing in popularity due to recent advances introduced into MS instruments, such as elevated-energy MS (MSe) [39] and sequential window acquisition of all theoretic mass spectra (SWATH) [40] acquisition modes.

When the protein or peptide is known, a targeted proteomics analysis can be done using an SRM analysis [22]. This LC-MS/MS acquisition mode in combination with complete protein digestion is considered the gold standard method for the quantification of proteins due to its high sensitivity and specificity. 


\subsubsection{Foodomics}

Foodomics, the application of systems biology approaches in food science using and integrating a variety of omics tools (e.g., proteomics, genomics, metabolomics, transcriptomics, lipidomics, microbiomics) [41] can greatly improve comprehensive knowledge of food quality by identifying markers for several features, such as food contaminants, food origin, and food authentication [42]. Interactomics and network analysis provide reference proteins and genes maps that can act as the base for further studies [43]. This can help to evaluate the supramolecular complexities, such as the formation of protein complexes or the interaction of proteins with other molecules [44]. Since these changes may introduce alterations in food functional properties, these integrated approaches could be used to assess the technological processes undergone by a food product [45]. Functional proteomics and systems biology can also help with the selection of which protein fragment to choose as a marker for a specific condition [46]. For example, protein fragments overlapping with linear epitopes are preferable if the same fragment is to be used in MS and immunochemical methods. Another example is the investigation of conserved protein domains among different species, which can extend the analytical opportunities (e.g., a peptide marker of crab tropomyosin may be used to detect shrimp meat).

Many tools are available to build and visually explore protein interaction networks according to regularly updated databases. Most of these algorithms, such as Ingenuity Pathway Analysis (Qiagen, Redwood City, CA), Cytoscape [47], and Pathway Studio [48], work on the basis of a web page where a list of interesting proteins can be uploaded and searched for their annotations in databases (these can be their own built-in databases or publicly available databases such as Gene Ontology [GO] [49], KEGG [50], or BIND [51]) and mapping them to known biological pathways and gene ontology terms. A comprehensive list of pathway and interaction databases can be downloaded from www.pathguide.org (accessed November 2015). Proteins are classified according to their functional roles, cell localization, biological process, and interaction. From this information, pathway and network information can be obtained. Although customized pathways and databases can be created in some of these tools, all of them use human and model organisms' databases. Therefore, work is needed to extend the applicability of these approaches to food technology-related studies. For instance, maize and rice protein networks are included in Pathway Studio, and pathways for chicken, cow, wild pig, and Saccharomyces cerevisiae are included in the Reactome database [52].

\subsection{APPLICATIONS IN FOOD AUTHENTICATION}

In the following sections, we describe studies that have used proteomic technologies for the assessment of food authentication in different kinds of foodstuffs. Although species authentication is the area of greatest activity, proteomics is also being applied to other food authentication issues such as breed identification, geographic origin, undeclared addition of plant/animal protein material and type of material added (e.g., milk/milk proteins, blood/its constituents), production method (wild/farmed), technological processing, proportion of ingredients used, and detection of GMOs (Figure 1.2). Table 1.1 lists the most recent proteomics-based studies. 


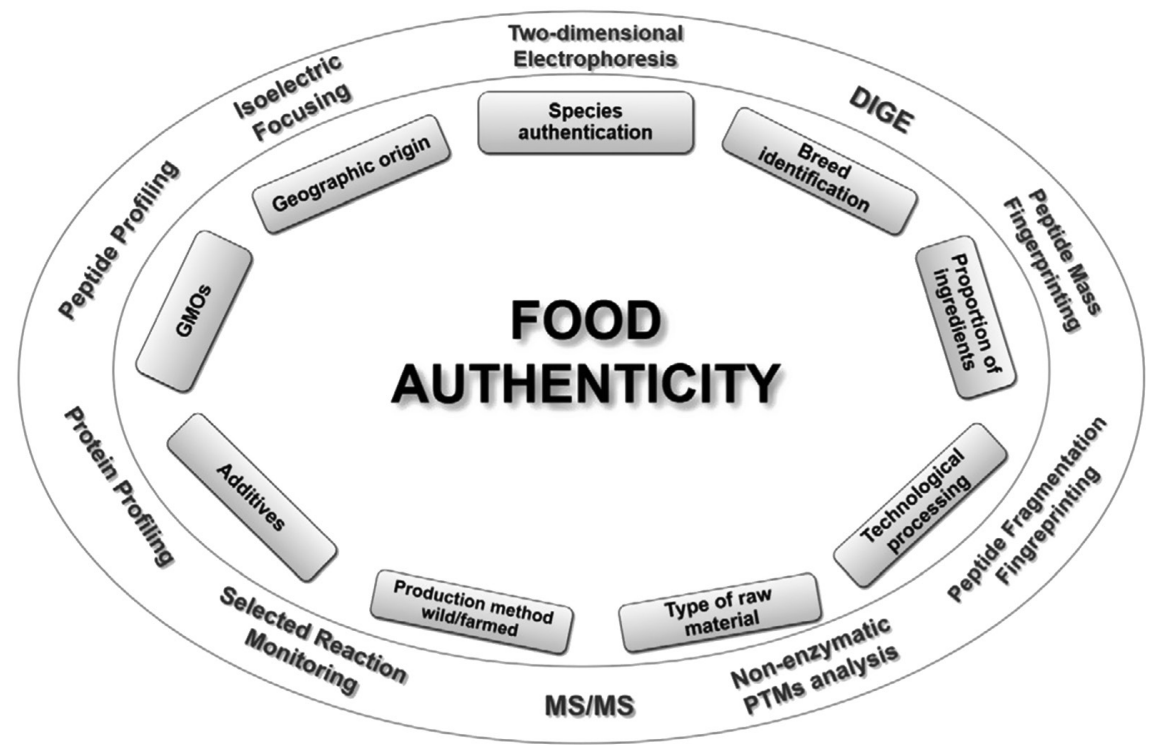

FIGURE 1.2 Current challenges associated with food authenticity (inner circle) that can be resolved by proteomic approaches (outer circle).

TABLE 1.1 Proteomic Approaches to Assess Authenticity of Food Products Published in the Last Six Years

\begin{tabular}{|c|c|c|c|c|}
\hline Food & Main Technique & Purpose of Analysis & Target & References \\
\hline \multirow{9}{*}{$\begin{array}{l}\text { Milk and } \\
\text { dairy } \\
\text { products }\end{array}$} & \multirow{6}{*}{$\begin{array}{l}\text { IEF } \\
\text { MALDI-TOF-MS } \\
\text { protein/peptide } \\
\text { profiling }\end{array}$} & Milk adulteration & Caseins & [55] \\
\hline & & Milk adulteration & Low Mr. proteins & [58] \\
\hline & & $\begin{array}{l}\text { Milk adulteration } \\
\text { and thermal } \\
\text { treatment }\end{array}$ & $\begin{array}{l}(\mathrm{b} 25 \mathrm{kDa}) \text {; several } \\
\text { milk proteins }\end{array}$ & [59] \\
\hline & & Milk adulteration & Caseins & [63] \\
\hline & & Milk adulteration & $\begin{array}{l}\text { Caseins and } \\
\beta \text {-lactoglobulin }\end{array}$ & {$[64]$} \\
\hline & & $\begin{array}{l}\text { Thermal treatment } \\
\text { in milk }\end{array}$ & $\begin{array}{l}\text { Casein } \\
\text { phosphopeptides }\end{array}$ & {$[60]$} \\
\hline & $\begin{array}{l}\text { 2-DE + PMF and } \\
\text { MALDI-TOF-MS } \\
\text { peptide profiling }\end{array}$ & $\begin{array}{l}\text { Adulteration of } \\
\text { fresh milk with } \\
\text { powdered milk }\end{array}$ & $\begin{array}{l}\text { Modified whey } \\
\text { proteins and/or } \\
\text { caseins }\end{array}$ & {$[68]$} \\
\hline & $\mathrm{MS} / \mathrm{MS} \mathrm{DDA}+\mathrm{PFF}$ & $\begin{array}{l}\text { Adulteration of } \\
\text { milk powder with } \\
\text { pea and soy } \\
\text { proteins }\end{array}$ & $\begin{array}{l}\text { Glycinin, } \\
\beta \text {-conglycinin, } \\
\text { legumin, vicilin }\end{array}$ & {$[66]$} \\
\hline & SRM & Cheese adulteration & Caseins & {$[65]$} \\
\hline Meat & 2-DE & $\begin{array}{l}\text { Differentiation of } \\
\text { meat species } \\
\text { (cattle, pork, } \\
\text { chicken, turkey, } \\
\text { duck, and goose) }\end{array}$ & Myosin light chains & {$[71,72]$} \\
\hline
\end{tabular}


TABLE 1.1 (CONTINUED) Proteomic Approaches to Assess Authenticity of Food Products Published in the Last Six Years

\begin{tabular}{|c|c|c|c|c|}
\hline Food & Main Technique & Purpose of Analysis & Target & References \\
\hline & & $\begin{array}{l}\text { Differentiation of } \\
\text { two pig breeds }\end{array}$ & Muscle proteins & [84] \\
\hline & & $\begin{array}{l}\text { Differentiation of } \\
\text { two cattle breeds }\end{array}$ & Liver proteins & {$[85]$} \\
\hline & 2-DE DIGE & $\begin{array}{l}\text { Differentiation of } \\
\text { two Norwegian } \\
\text { breeds }\end{array}$ & $\begin{array}{l}\text { Muscle water- } \\
\text { soluble proteins }\end{array}$ & [83] \\
\hline & $\begin{array}{l}\text { MALDI-TOF-MS } \\
\text { peptide profiling }\end{array}$ & $\begin{array}{l}\text { Species } \\
\text { identification ( } 32 \\
\text { mammal species) }\end{array}$ & Collagen & [76] \\
\hline & MS/MS DDA & $\begin{array}{l}\text { Detection of } \\
\text { chicken meat in } \\
\text { meat mixes }\end{array}$ & Myosin light chain 3 & [77] \\
\hline & & $\begin{array}{l}\text { Detection of horse } \\
\text { meat in meat } \\
\text { mixes }\end{array}$ & $\begin{array}{c}\text { Myosin and } \\
\text { myoglobin }\end{array}$ & [78] \\
\hline & pSRM & $\begin{array}{l}\text { Detection of beef, } \\
\text { horse, pork, and } \\
\text { lamb meat in meat } \\
\text { mixes }\end{array}$ & Myoglobin & {$[82]$} \\
\hline & SRM & $\begin{array}{l}\text { Detection of horse } \\
\text { and pork in beef }\end{array}$ & $\begin{array}{l}\text { Troponin, myosin, } \\
\text { myoglobin, } \\
\text { hemoglobin, } \\
\text { pyruvate kinase }\end{array}$ & [79] \\
\hline & & $\begin{array}{l}\text { Detection of cooked } \\
\text { pork meat }\end{array}$ & $\begin{array}{l}\text { Albumin and lactate } \\
\text { dehydrogenase }\end{array}$ & {$[80]$} \\
\hline & & $\begin{array}{l}\text { Detection of beef, } \\
\text { pork, horse, and } \\
\text { lamb meat in meat } \\
\text { mixes }\end{array}$ & Myoglobin & [81] \\
\hline \multirow[t]{6}{*}{ Shellfish } & Native IEF & $\begin{array}{l}\text { Differentiation of } \\
\text { shrimp species }\end{array}$ & $\begin{array}{l}\text { Sarcoplasmic } \\
\text { calcium-binding } \\
\text { proteins }\end{array}$ & {$[90]$} \\
\hline & $2-\mathrm{DE}$ & $\begin{array}{l}\text { Discrimination of } \\
\text { two scallop } \\
\text { populations }\end{array}$ & Mantle proteins & [94] \\
\hline & 2-DE and PMF & $\begin{array}{l}\text { Differentiation of } \\
\text { shrimp species }\end{array}$ & Arginine kinase & {$[95]$} \\
\hline & \multirow[t]{2}{*}{$\mathrm{MS} / \mathrm{MS} \mathrm{DDA}+\mathrm{PFF}$} & $\begin{array}{l}\text { Differentiation of } \\
\text { shrimp species }\end{array}$ & Arginine kinase & [96] \\
\hline & & $\begin{array}{l}\text { Pandalus borealis } \\
\text { markers }\end{array}$ & Arginine kinase & [97] \\
\hline & pSRM & $\begin{array}{l}\text { Differentiation of } \\
\text { shrimp species }\end{array}$ & Arginine kinase & {$[98]$} \\
\hline
\end{tabular}


TABLE 1.1 (CONTINUED) Proteomic Approaches to Assess Authenticity of Food Products Published in the Last Six Years

\begin{tabular}{|c|c|c|c|c|}
\hline Food & Main Technique & Purpose of Analysis & Target & References \\
\hline & $\begin{array}{l}\text { MALDI-TOF-MS } \\
\text { protein profiling } \\
\text { library }\end{array}$ & $\begin{array}{l}\text { Differentiation of } \\
\text { shrimp species, } \\
\text { geographic origin, } \\
\text { and fresh/frozen } \\
\text { state }\end{array}$ & Muscle proteins & [99] \\
\hline \multirow[t]{4}{*}{ Fish } & 2-DE & $\begin{array}{l}\text { Differentiation of } \\
\text { tuna species }\end{array}$ & Muscular proteins & {$[106,107]$} \\
\hline & $\begin{array}{l}\text { 2-DE, PMF, and } \\
\text { MS/MS }\end{array}$ & $\begin{array}{l}\text { Discrimination of } \\
\text { two river fish } \\
\text { species }\end{array}$ & $\begin{array}{l}\text { Triose phosphate } \\
\text { isomerase }\end{array}$ & {$[111]$} \\
\hline & $\begin{array}{l}\text { MS/MS spectral } \\
\text { library }\end{array}$ & $\begin{array}{l}\text { Differentiation of } \\
\text { fish species }\end{array}$ & Muscle proteins & [116] \\
\hline & pSRM & $\begin{array}{l}\text { Differentiation of } \\
\text { hake species }\end{array}$ & Parvalbumins & [113] \\
\hline \multirow[t]{8}{*}{ Wine } & $\begin{array}{l}\text { MALDI-TOF-MS } \\
\text { fingerprinting }\end{array}$ & $\begin{array}{l}\text { Discrimination of } \\
\text { white wine } \\
\text { varieties }\end{array}$ & Wine proteins & [119] \\
\hline & & $\begin{array}{l}\text { Classification of } \\
\text { Croatian white } \\
\text { wines }\end{array}$ & $\begin{array}{l}\text { Wine protein and } \\
\text { peptides }\end{array}$ & {$[120]$} \\
\hline & MS/MS DDA + PFF & $\begin{array}{l}\text { Addition of fining } \\
\text { agents in white } \\
\text { wines }\end{array}$ & Caseins & {$[30]$} \\
\hline & & $\begin{array}{l}\text { Addition of fining } \\
\text { agents in red wines }\end{array}$ & Caseins & {$[122]$} \\
\hline & & $\begin{array}{l}\text { Ingredient } \\
\text { verification for } \\
\text { commercial } \\
\text { aperitif }\end{array}$ & Soluble proteins & {$[34]$} \\
\hline & $\begin{array}{l}\text { MS/MS DDA+PFF } \\
\text { and XIC }\end{array}$ & $\begin{array}{l}\text { Addition of fining } \\
\text { agents in white } \\
\text { wines }\end{array}$ & Caseins & {$[124,125]$} \\
\hline & MS/MS DIA & $\begin{array}{l}\text { Addition of fining } \\
\text { agents in white } \\
\text { wines }\end{array}$ & $\begin{array}{l}\text { Casein, lysozyme, } \\
\text { and ovalbumin }\end{array}$ & [126] \\
\hline & SRM & $\begin{array}{l}\text { Addition of fining } \\
\text { agents in white } \\
\text { wines }\end{array}$ & Lysozyme & [123] \\
\hline \multirow[t]{2}{*}{ Honey } & $\begin{array}{l}\text { MALDI-TOF-MS } \\
\text { protein profiling }\end{array}$ & Geographic origin & $\begin{array}{l}\text { Water-soluble honey } \\
\text { proteins }\end{array}$ & {$[148]$} \\
\hline & $2-\mathrm{DE}$ & Floral origin & $\begin{array}{l}\text { Water-soluble honey } \\
\text { proteins }\end{array}$ & [149] \\
\hline Gelatin & MS/MS DDA + PFF & Species used & Collagen & {$[150]$} \\
\hline
\end{tabular}


TABLE 1.1 (CONTINUED) Proteomic Approaches to Assess Authenticity of Food Products Published in the Last Six Years

\begin{tabular}{|c|c|c|c|c|}
\hline Food & Main Technique & Purpose of Analysis & Target & References \\
\hline \multirow[t]{11}{*}{ GMOs } & $2-\mathrm{DE}$ & $\begin{array}{l}\text { Comparison of GM } \\
\text { and non-GM } \\
\text { maize }\end{array}$ & Kernel proteome & [138] \\
\hline & & & Leaf proteome & [139] \\
\hline & & & Grain proteome & [140] \\
\hline & & & Leaf proteome & [141] \\
\hline & & $\begin{array}{l}\text { Comparison of GM } \\
\text { and non-GM } \\
\text { soybean }\end{array}$ & Seed proteome & {$[133,134]$} \\
\hline & & $\begin{array}{l}\text { Comparison of GM } \\
\text { and non-GM } \\
\text { common bean }\end{array}$ & Grain proteome & {$[142]$} \\
\hline & & $\begin{array}{l}\text { Comparison of GM } \\
\text { and non-GM } \\
\text { potato }\end{array}$ & Leaf proteome & [135] \\
\hline & & & Tuber proteome & [135] \\
\hline & 2-DE DIGE & $\begin{array}{l}\text { Comparison of GM } \\
\text { and non-GM rice }\end{array}$ & Seed proteome & [143] \\
\hline & $\begin{array}{l}\text { LC-MS/MS with } \\
\text { isobaric labeling }\end{array}$ & $\begin{array}{l}\text { Comparison of GM } \\
\text { and non-GM rice }\end{array}$ & Seed proteome & {$[144]$} \\
\hline & LC-MS XIC & $\begin{array}{l}\text { GM and non-GM } \\
\text { tomato varieties }\end{array}$ & Fruit proteome & {$[145]$} \\
\hline
\end{tabular}

\subsubsection{Milk and Dairy Products}

The adulteration of cheese with less expensive milk is one of the main problems in the dairy industry. The reference method for determining the presence of cow's milk in ewe's and/or goat's cheese is based on the detection of the bands for cow $\gamma 2$ - and $\gamma 3$-caseins on an IEF gel [53] and has proven successful in verifying the presence of cow casein $[54,55]$. In general, this reference method is performed as a qualitative technique using certified reference materials with $0 \%$ and $1 \%$ cow's milk. At these levels, the marker bands for bovine milk ( $\gamma_{2}$-and $\gamma_{3}$-caseins) are not visible when staining the gel with Coomassie blue; therefore, a milk sample having at least 5\% cow's milk has to be run in parallel to ascertain the position of these bands on the gel [55]. Moreover, for cheese samples below $5 \%$ cow's milk, the marker bands could not be detected using the most common staining method. Other problems reported in relation to this method are interfering bands causing false-positive responses and the need for an excellent electrophoretic separation of $\gamma$-caseins [54]. The method can yield ambiguous results in some cases, and more resolute and sensitive techniques should be used to complement it.

MS-based [1] (as opposed to MS/MS-based) protein profiling, using either matrixassisted laser desorption/ionization-time of flight (MALDI-TOF) or electrospray ionization (ESI)-MS, has been extensively investigated for the possible detection of fraudulent practices in the dairy industry. The use of the MS protein profiling method provides a shorter analysis time due to a faster sample preparation step that skips protein digestion. 
MALDI-TOF protein profiling was used for the investigation of the addition of bovine milk to ewe and buffalo's milk [56] and in the adulteration of mozzarella cheese [57], using whey proteins as biomarkers. The same technique has been used to reveal the adulteration of donkey and goat's milk with cow, ewe, and buffalo's milk at levels down to $0.5 \%$ [58]. Recently, Sassi et al., using a similar method, identified not only markers of bovine, water buffalo, ovine, and goat's milk, but also markers of thermal treatments [59]. MALDI-TOF-MS has also been used to detect the addition of ultra-high temperature (UHT) milk to raw or pasteurized milk with a limit of detection (LOD) of $10 \%$ [60]. ESI-MS has also been applied to milk adulteration. The protein $\beta$-lactoglobulin was used for the detection and quantification of bovine milk in goat [61] caprine or ovine milk [62] by means of HPLC-ESI-MS or capillary electrophoresis-MS. The presence of cow's milk was detected at levels not lower than $5 \%$.

MS'-based peptide profiling incorporates a digestion step in the sample preparation workflow. Comparisons between sample groups are then based on specific peptides instead of proteins. Casein tryptic peptides were used in detecting and quantifying milk adulteration by means of MALDI-TOF and LC-ESI-MS analysis, which were able to detect bovine, ovine, buffalo, and caprine milk as low as $0.5 \%$ in milk mixtures [63]. In this work, synthetic peptide analogs of the natural specific peptides were used, which increased accuracy and specificity. Calvano et al. [64] described a method combining insolution digestion of whole milk samples and MALDI-TOF analysis of the tryptic digests which was able to detect a 5\% level of cow and goat's milk adulteration.

Although these $\mathrm{MS}^{1}$-based methods perform well in simple matrices such as milk, specificity could be compromised when a more complex background matrix is analyzed. In these cases, the extra specificity that MS/MS-based methods can achieve by providing amino acid sequence information could help in preventing false positives and negatives and in achieving better accuracy in quantitative assays. Guarino et al. [65] reported an LC-MS/MS method for the detection and quantification of sheep's milk in goat and cow's cheese. After plasmin digestion of the caseins extracted from the cheese samples, one peptide specific for sheep was selected. An SRM method targeting this marker peptide was then optimized and the analytical performance of the method was reported. For quantification, calibration curves were built using cheeses containing different percentages of the three types of milk. Using this approach, the authors reported the detection of as low as $2 \%$ of sheep's milk in goat and cow's cheeses. MS/MS analysis was also applied to the detection of soy and pea proteins added to skimmed milk powder (SMP) [66]. Masses from the peptides showing differential behavior between adulterated SMP and control SMP samples were obtained by MS; the product ion spectra corresponding to these peptides were then generated and the peptides and proteins identified by database searching. The source of the adulteration (pea or soy) was therefore identified. However, no different varieties/cultivars of soy and pea were used to check for intraspecies variability. Moreover, a method based on ultra-high-performance liquid chromatography and ultraviolet (UV) detection has been published that outperformed this MS/MS-based method since it was able to detect the adulteration of skimmed milk powder with soy, pea, rice, and hydrolyzed wheat protein isolates in the same analysis [67].

The addition of reconstituted milk (powder milk) to fresh milk is forbidden in some circumstances, such as the production of protected designation of origin cheeses [5], making it necessary to develop methodologies for detecting this kind of adulteration. Although the adulterant material, namely, the powder derivative, would have the same composition and even the same proteins as liquid milk, protein modification can occur during milk powder production due to the high temperatures used; therefore, proteomics 
methodologies could help to detect this illegal practice. Calvano et al. [68] detected differences among liquid and powder milk using 2-DE, and lactosylated diagnostic peptides for powdered milk were identified by MALDI-MS. By detecting these marker peptides in milk samples adulterated with powdered milk subjected to in-solution digestion of the proteins, as little as $1 \%$ adulteration could be detected.

\subsubsection{Meat}

In 1993, ESI-MS of intact proteins was highlighted as a potential method for meat speciation [69]. Although the method was able to differentiate between pork, beef, sheep, and horse origin, and the target proteins, namely, hemoglobin and myoglobin, showed a high degree of heat stability, only pure commercial proteins were used and no actual meat material was tested. In a subsequent study, this time using ESI-MS/MS on intact myoglobin extracted from beef and pork, and commercial proteins from horse and sheep, Ponce-Alquicira and Taylor [70] were able to differentiate sheep and beef from each other and from horse and pork, but instrument resolution was not enough to differentiate horse and pork. This issue is likely to be resolved with the current array of high-resolution mass spectrometers.

Montowska and Pospiec [71,72] found interspecies differences in 2-DE protein patterns between cattle, pig, chicken, turkey, duck, and goose, in both raw meat and processed products. Some of the proteins were stable during meat aging and resistant to thermal processing, and some of them could even be identified in highly processed products such as fermented sausages and were therefore proposed as suitable markers. However, a validation study focusing on amino acid sequence information from these stable proteins would be necessary in order to establish a high-throughput targeted MS/ MS-based method, such as SRM, for the differentiation of the species. This requirement is strengthened by the fact that for duck and goose there is still little protein sequence information in current databases.

The adulteration of meat has also been investigated by means of MS/MS. Using 2D-LC-MS/MS, Leitner et al. [73] reported a method for detecting soybean proteins added to processed meat products. The presence of unique peptides from a glycinin subunit was consistently found in the four different commercial heat-processed meat products (from pork, chicken, turkey, and beef). Grundy et al. [74,75] were able to detect as low as $5 \%$ bovine or porcine blood-based gelling agents spiked in different food matrices (minced pork, beef, chicken, lamb, tuna, and cod) by the SRM detection of bovinespecific fibrinopeptides. The method was validated by analyzing 18 commercial readymeal products with various coatings and sauces. Fibrinopeptides could not be detected in spiked cod, and the authors suggested a possible cleavage by a cod peptidase to explain it.

Buckley et al. [76] present a robust method for analyzing genus-specific collagen peptides extracted from bone fragments in 32 different mammal species, identifying a total of 92 peptide markers that could be used for species identification, for example, in processed food and animal feed. Cattle, pig, sheep, and chicken meat and processed bone meal samples were also analyzed. To reduce intraspecies variation, different individuals were sampled, for sheep $(n=10)$ and goat $(n=7)$, where different breeds were considered (two and three breeds, respectively). To simplify the analysis, on-tip C18 solid phase extraction instead of LC, before MALDI-TOF-MS/MS, was used. Sentandreu et al. [77] developed an LC-MS/MS methodology, with in-solution isoelectric focusing fractionation, to detect chicken in meat mixes. The extracted ion chromatograms for two 
chicken-specific peptides from myosin light chain 3 were used to calculate the amount of peptides after normalization with spiked synthetic peptides. Even though the MS acquisition method and instrument used, namely, DDA and LCQ IT (LCQ ion trap), are not the most sensitive choices, the method reported allowed the detection of as low as $0.5 \%$ chicken meat in pork meat and can be applied to both raw and cooked meats. The use of stable isotope labeled peptides as an internal standard for normalization assures the highest accuracy in these kinds of assays. Processed and raw horse meat were detected in meat mixtures at $0.5 \%$ levels using heat-stable species-specific peptides, also using a DDA method [78]. Von Bargen et al. [79] developed an SRM method for the detection of horse and pork in beef. After identifying the biomarker peptides by a shotgun MS/ MS-based approach, peptides specific to horse and pig were included in an SRM assay capable of detecting as low as $0.55 \%$ horse or pork contamination in a beef matrix, or $0.13 \%$ pork contamination in beef when an $\mathrm{MS}^{3}$ method was used. Different raw meat samples were analyzed $(n=21)$, although there was no validation in processed meats, where sensitivity is expected to be reduced. Four thermostable peptides were suggested as markers for pork detection in cooked meat products using SRM [80], although only pork meat samples were analyzed, and therefore the method was not tested on mixed commercial meat products. SRM and pSRM have also been used in the detection of beef, pork, horse, and lamb myoglobin in meat mixes [81,82], although quantitative data presented in the studies were preliminary. Moreover, some of the monitored peptides were shared by other species such as donkey, goat, buffalo, dog, and rabbit.

It is also possible to identify animals between individual breeds on the basis of proteomic analyses using the 2-DE technique. Using DIGE, differences in protein abundance between two different Norwegian pig breeds, Landrace and Duroc, were investigated [83]. A total of 94 proteins were significantly changed in their relative abundance according to an analysis of variance (ANOVA) and multivariate statistical analysis, and 50 of them were identified by PMF and PFF analysis. Variability due to age was addressed, since three age groups were compared. In a similar study [84], 25 protein spots were found to be differentially expressed in two pig breeds, Meishan and Large White. This study used silver-stained gels instead of DIGE technology but had less statistical power due to the reduced number of biological replicates (three per group). Several proteins $(n=14)$ were identified by MALDI-TOF PMF, and seven of them were validated using quantitative real-time polymerase chain reaction (qRT-PCR). In another study comparing the cattle breeds Holstein and Chianina, differences in the expression levels of 39 proteins were observed using 2-DE with Coomassie staining [85]. However, since protein extracts were obtained from liver, results cannot be extrapolated to muscle tissue or "meat". In all these studies assessing inter-breed variability, differences due to the environment were not addressed, since all the samples within a breed came from the same farm and were fed the same diet.

\subsubsection{Shellfish}

Seafood products, including shellfish and fish, are among the most internationally traded food commodities. Because of the great phenotypic similarity between related species, different kinds of intentional or inadvertent adulteration can occur, such as the substitution of a highly valuable species for a similar but cheaper one, or the labeling of an aquaculture-obtained product as fished wild. Therefore, legislation has appeared all over the world to guarantee authenticity and traceability in the trading of these products. 
For example, European legislation [7] advises that the labeling of seafood products should indicate the commercial designation of the species, the production method (wild or farmed), and the geographic area in which the shellfish or fish was caught or farmed. Therefore, proper analytical methodologies should exist to assess these requirements.

In the pioneer studies by An et al. [86,87], it was demonstrated that electrophoretic protein profiles could be used for differentiating very closely related species. Although limited to only three shrimp species, and no information about the sampling was provided, they were able to differentiate them using SDS-PAGE or IEF of the proteins from muscle samples. SDS-PAGE and IEF gels have also been used for the differentiation of shrimp from crab meat and from fish, lobster, and cephalopod meat, respectively $[88,89]$. However, in all these studies, it was shown that no single extraction method or electrophoretic system was valid for all applications: SDS-PAGE and IEF of the sarcoplasmic, water-soluble proteins, worked well for differentiating raw samples, while SDS extracts performed better for cooked muscle. Moreover, no extensive sampling was done, and gels were analyzed visually, without any kind of statistical analysis.

Water-soluble muscular proteins were used in a study to differentiate shrimp and prawn species of commercial interest using native IEF with subsequent identification of the species-specific proteins by LC-MS/MS [90]. This study represents the most complete electrophoretic study described to date for the identification of closely related species as the 14 shrimp and prawn species studied were unambiguously identified, and different populations were included for some of the species, thereby assessing intraspecies variability. The $\mathrm{pI}$ of the marker protein bands was reported using image analysis software and thus the results can be used as a reference database for the identification of unknown samples. No cooked samples were analyzed, but the fact that the species-specific proteins were identified as heat-stable sarcoplasmic calcium-binding proteins (SCPs) extends the potential application of the method to heat-processed and ready-to-eat products, although it has yet to be proven. Moreover, SCPs have been established as crustacean allergens [91], so a method targeting this group of proteins would have an impact on food safety in addition to food authenticity.

2-DE has also been used for studying quantitative differences between two marine mussel species [92]. Several protein spots $(n=37)$ were found to be differentially expressed by a computer-assisted analysis of silver-stained 2-DE gels, although only 15 of them were identified by means of PMF or PFF analysis. However, the authors noted that the differences observed could be caused by environmental variations in addition to genetic variability since each species originated from a different geographic location. In a subsequent study, the same authors reported species-specific peptides for the three European marine mussel species by combining 2-DE protein isolation, PMF analysis of prominent protein spots, and product ion peptide de novo sequencing [93]. The specific peptides could also be detected using single ion monitoring (SIM), which is known to improve sensitivity but can lack specificity in some instances. Although only four biological replicates from each of the three species were considered, the study represented the first application of a complete bottom-up proteomics approach to species authentication.

In a recent study, 2-DE was used for the discovery of potential biomarkers for discriminating between two populations of the great scallop [94]. Several protein spots $(n=38)$ were found to be differentially expressed, although only 11 of them could be identified by MS/MS analysis. The study considered the implications of physiological and temporal variability since animals of similar sizes were collected at two different time points and comprised a similar development state for all the scallops. Since no technical replicates were reported (which are generally needed when 2-DE gels are stained 
with Coomassie blue to address biases due to gel-to-gel variability), the results should be treated with caution until a verification experiment with a different technique and including a higher number of samples is performed. However, this preliminary study is a good example of the potential of proteomics to discriminate populations living in contrasting environments.

The sarcoplasmic protein arginine kinase (AK) was proposed as a biomarker for Decapoda species identification due to its variability found in 2-DE profiles [95]. PMF spectra of AK were used as a marker for the authentication of six shrimp species of commercial relevance. Although the number of biological replicates was relatively low, this study represents the first study dealing with species differentiation by MS-based proteomics, where data was statistically analyzed instead of the common visually reporting of differences between species. Specifically, a PMF spectra clustering method was developed that can help in the classification of unknown samples by comparing them with reference samples. In a subsequent study, several species-specific peptides from AK that can serve as diagnostic peptides for the identification of the seven most commercial shrimp and prawn species were identified and characterized by means of de novo sequencing of the corresponding product ion spectra $[96,97]$. Although samples from different populations/geographic regions were used for some of the analyzed species, possible variability due to seasonal changes was not addressed. Since the sequences of the species-specific peptides were reported, they can be used as a reference for the identification of unknown samples. Moreover, identified species-specific peptides paved the way for developing fast and easy-to-use methods for the sensitive detection of the species, such as immunoassays via antibody development, or targeted MS assays. Actually, a pSRM assay for the identification of the seven most commercial shrimp species, targeting those previously characterized peptides, was reported and validated using commercial samples [98]. This method includes very fast sample preparation using high-intensity focused ultrasound and the complete analysis including sample processing and pSRM takes $90 \mathrm{~min}$. This can be further reduced to $45 \mathrm{~min}$ if the LC is skipped and the samples are analyzed offline, since this approach resulted in the same outcome as when using the online LC. One extra advantage of pSRM methods over other targeted MS methods, such as SIM or SRM, is that, in PSRM, the product ion spectra of the target peptides are registered, yielding a higher specificity. To increase the specificity of SRM assays, most QqQ now include the option of acquiring a triggered product ion scan, although it is not yet in common use.

Finally, Salla and Murray [99] have reported a method for the MALDI-TOF-MS protein profiling of shrimp muscle proteins. Unknown samples $(n=74)$ were compared to a mass spectra library previously generated using reference specimens from six shrimp species. The commercial software MALDI BioTyper (Bruker Daltonics, Billerica, MA) was used for library generation and mass spectra comparison, and $97 \%$ accuracy for species-level matching was reported. The method was able to correctly classify shrimps from several geographic origins for two of the species, and with different sizes and fresh/ frozen state for one of the species. The great advantage of this method is the speed of analysis due to the fast sample preparation step that avoids protein digestion, but the main drawback of this type of analysis based on only one stage of mass spectrometry analysis (MS ${ }^{1}$ or MS) is that only the mass of the analyte is obtained. Thus, since the peptide or protein is not being fragmented and no product ion spectra are being obtained, no structural information is derived. The comparison in this approach is made purely on pattern recognition, and since no unique biomarker is reported, an extensive validation of such an approach would be essential. 


\subsubsection{Fish}

As for shellfish, classical electrophoretic techniques such as SDS-PAGE and IEF have been extensively used for fish species authentication. In an interlaboratory study carried out by nine laboratories, the performance of optimized SDS-PAGE and urea-IEF standard operation procedures were evaluated for the identification of 10 commercial fish species after cooking [100]. It was concluded that both methods performed differently depending on the species, and therefore the use of both methods was advised for species differentiation. The need for proper reference samples to run in parallel with the unknown sample being analyzed is one of the main issues associated with electrophoretic methodologies. As an alternative, it has been proposed to build a library of reference gel images stored at public repositories, such as the Gel Library of the US Food and Drug Administration (www.fda.gov/Food/FoodScienceResearch/RFE, accessed November 2015), based on Official Method 980.16 (AOAC, 1995). Thus, Bossier and Cooreman [101] built a computerized databank of IEF protein profiles from 17 flatfish species and checked it for the authentication of 17 commercial fish fillets. Interspecimen variability was assessed for some of the species by analyzing up to three specimens, although no information about different populations or geographic regions was reported. The authors concluded that intraspecies similarity was larger than interspecies similarity, although it has to be noted that this could be due to samples from one species being collected from the same geographic region. Renon et al. [102] used the IEF sarcoplasmic protein pattern to distinguish between swordfish, blue marlin, and Mediterranean spearfish, in fresh, frozen, and cold-smoked fillets, although only one biological replicate for swordfish and marlin, and two for spearfish, were used.

Since the 1990s, differences in the qualitative 2-DE profiles of water-soluble muscular proteins have been used to discriminate between fish species such as gadoid fishes [103], flat fishes [104], and hake species [105]. In these studies, several specimens from distant fishing banks were investigated for some of the species in order to assess for intraspecies variability, and three to four biological replicates for each species or geographic location were considered. Technical replicates were included and gel images were computer processed, thereby increasing the power of the analysis. Since the differential proteins found were tentatively identified as parvalbumins, a group of heat-resistant sarcoplasmic proteins, it was claimed that the methodologies described could be used for the identification of those fish species in heat-treated products. Nucleoside diphosphate kinase A (NDK A) was also identified as a marker protein for the identification of hake species. Other proteins that have demonstrated potential for discriminating fish species by 2-DE are triose phosphate isomerase, pyruvate kinase, troponin $\mathrm{T}$, and beta-enolase, which have been proposed as potential markers for the tuna species Thunnus thynnus, Th. alalunga, Th. albacares, and Th. obesus, respectively $[106,107]$. However, further research, including a higher number of biological replicates from the different population/origins and technical replicates for assessing the inter-gel variability, would be needed to validate the results obtained. Myosin light chain (MLC) isoforms were proposed for the differentiation of cod, saithe, haddock, mackerel, and capelin [108], although no sampling information was reported. Interestingly, MLCs also enabled the differentiation of breeding stock, showing observable differences in two stocks of Arctic char (Salvelinus alpinus). 2-DE also achieved the differentiation of five puffer fish species using urea-soluble protein extracts from the muscle of three specimens of each species [109], although the potential speciesspecific proteins were not further characterized and thus not identified. Martínez et al. [110] were able to differentiate wild from farmed cod using 2-DE. Several spots were 
found to have different electrophoretic mobility, and other spots were absent in wild but present in farmed cod samples. However, the spots were not sequenced so the proteins were not identified. The main drawback of this study was the lack of statistical analysis, since electrophoretic profiles were only visually checked. Moreover, no source of intragroup variability, such as population or development-related differences, was assessed.

PMF and PFF provide some advantages over 2-DE since they allow the identification of the protein, which is useful for the direct comparison and classification of samples. Combining 2-DE with PMF and PFF, differences in the muscular proteins from two commercially important river fish species from the genus Sperata were investigated [111]. Several species-specific proteins $(\mathrm{n}=11)$ were identified, and triosephosphate isomerase isoforms were proposed as specific markers. Using a similar approach, the suitability of the PMF spectra of the proteins in the parvalbumin fraction for the classification of 10 hake species was tested [112]. Six species could be identified, while the other four species were grouped in two clusters. Two subspecies from one of the species could also be differentiated. The work was completed with the development of a pSRM assay targeting the differential parvalbumin peptides, using five reference specimens for each of the 11 commercial hake species studied [113]. The method differentiated all but four species, these four were grouped in two clusters, and was able to distinguish between the two subspecies for one of the species. Ten commercial hake foodstuffs were used for validation, comprising only five of the species. Since parvalbumins are heat-resistant proteins, the methodology can be applied to processed and cooked products. Following 2-DE analysis, PMF, and PFF de novo sequencing of the protein NDK B, the same authors reported a set of specific peptides that can help in the classification of the 11 hake species [114]. However, only two of the species could be completely differentiated from the others, while the other nine species were grouped in two clusters comprising several species each.

Mazzeo et al. [115] developed a MALDI-TOF protein profiling method able to obtain specific profiles for 25 different fish species. Signals observed around $11 \mathrm{kDa}$, and subsequently identified as parvalbumins, were selected as specific biomarkers. Commercial fish products (fillets and fish sticks) were also successfully analyzed. Although five biological replicates were used, variability due to population or geographic changes was not addressed. However, the work represents the highest number of species included in a fish authentication study, and possibly the fastest method to date, since the sample preparation step and the MALDI analysis take only a few minutes.

Wulff et al. [116] demonstrated the suitability of a completely different proteomewide approach for fish species differentiation. They first generated a reference product ion spectral library using muscle samples from 22 different species. "Unknown" samples, both fresh and heavily processed, could then be unambiguously identified by comparison to the spectral library. Although the datasets from the fresh "unknown" samples were replicates of the same samples that had been used for the library generation, 21 out of 25 heavily processed samples were correctly identified, showing the potential of this direct spectral matching method. The method does not require genome or protein databases; it uses all acquired product ion data (therefore there is no need for selection or filtering of spectra), and it uses an automated and standardized workflow.

\subsubsection{Wine}

Traceability and quality control in the wine industry have attracted much attention in recent years. Proteomics-based techniques can be used not only to investigate methods 
for distinguishing and classifying different wines, such as different vintages or different grape varieties, but also to detect and quantify non-declared additions of non-wine proteins such as fining agents. Nevertheless, protein and peptide analysis techniques have not yet been fully exploited to study authenticity topics in wine and other alcoholic and non-alcoholic beverages. The main reason is that, in these kinds of samples, proteins are present only at trace levels due to the filtering steps during industrial processing and the usual removal of the residual proteins from the finished product. Moreover, only a small amount of the proteins from the raw material survives the fermentation process and they tend to aggregate leading to sediments, so only small-size species or small fragments from the proteolysis of high-molecular-mass components remain after industrial manipulations [117]. The presence of exogenous proteins (e.g., yeast, bacteria, and fungi) further complicates the use of protein or peptide fingerprinting to identify frauds or authenticate origin, composition, variety, or vintage. Therefore, sample preparation, mainly protein extraction and enrichment, is critical, affecting not only the number of proteins identified, but also the reproducibility of results. The use of CPLLs for protein enrichment has been reported to greatly increase not only the proteome coverage, as 100 grape proteins can be identified in wine, but also the sensitivity (down to a few $\mathrm{ng} \mathrm{mL} \mathrm{m}^{-1}$ could be detected for some proteins) and reproducibility [117,118].

Chambery et al. [119] applied a peptide profile fingerprint approach using MALDITOF-MS for the differentiation of three white wine varieties. The MALDI spectra revealed differences between the wines after analysis with principal component analysis (PCA) and cluster analysis, but since only a few representative samples were analyzed, these differences cannot be considered as markers for the grape variety. Furthermore, one of the main drawbacks of protein/peptide profile methodologies of wine is that, since peptides are not identified, error in the classification of a wine sample can be induced because of the presence of exogenous proteins, such as those from yeast or fungi. Therefore, some exogenous peaks can appear in the MS spectrum when analyzing one bottle of wine but may not appear in another from the same vintage or grape variety. An intra-sample study in which a series of bottles of the same wine group are checked for fingerprint pattern changes should be done to resolve this issue. In a recent study [120], MALDI-TOF fingerprinting followed by unsupervised statistical methods showed potential for wine type classification, although the method was not able to distinguish between all 33 Croatian white wine types that were included in the analysis. LC-MS/MS following CPLL protein capture was used to prove the genuineness of a commercial liqueur, stated to be of plant origin [34]. Proteins from the species declared on the product label were identified, although proteins from other vegetable species were also found but not identified due to lack of database entries for most of the plants.

From July 2012, wine fining agents above $0.25 \mathrm{mg} \mathrm{L}^{-1}$ must be declared on the wine label $[6,121]$. Casein and lysozyme are the two most popular fining agents added to wine to remove the residual proteins from the finished product, and they are also major food allergens from milk and egg, respectively. Therefore, reliable methods enabling the detection of these added proteins at trace levels are needed. Casein has been detected by DDA, with previous enrichment using combinatorial peptide ligand libraries and a further isolation of the target protein casein by SDS-PAGE, with LOD values as little as 1 and $3.8 \mu \mathrm{g} \mathrm{L}^{-1}$, for white and red wines, respectively $[30,122]$. However, the complexity of the sample treatment was not ideally suited to high-throughput analysis. Moreover, as stated in Section 1.2.5, since information about the target protein/peptides is known, the use of targeted MS analysis is recommended for better specificity and sensitivity. Cryar et al. [123] reported an SRM method targeting three tryptic peptides from lysozyme. 
Using stable isotopic dilution (SID) experiments for the quantification of 1 ppm lysozyme in white wine, an uncertainty as low as $3 \%$ was reached. Monaci et al. [124,125] were able to detect casein in white wines at $100 \mu \mathrm{g} \mathrm{mL}^{-1}$ using LC-MS/MS DDA on a quadrupole-time of flight (Q-TOF) mass spectrometer, or at $1.6 \mu \mathrm{g} \mathrm{mL} \mathrm{m}^{-1}$ when the production ion spectra were generated on a high-resolution Orbitrap mass spectrometer. When using high-energy collision dissociation (HCD) DIA in a high-resolution instrument, the extracted ion chromatograms of eight specific peptides allowed the multiplex determination of casein, lysozyme, and ovalbumin in white wines with LODs ranging from 0.4 to $1.1 \mu \mathrm{g} \mathrm{mL}^{-1}$ [126]. Multiplexing the three proteins in the same assay allows the simultaneous detection of traces of caseinate and egg-white powder potentially remaining in white wines after fining.

\subsubsection{GMOs}

More than 40 countries have recently adopted labeling regulations regarding GM food [127]. For instance, EU regulation mandates the labeling of food and feed containing a $0.9 \%$ threshold for GM ingredients [4]. In the USA, although the FDA has refused to require labeling of GM foods since 1992, the development of a GM food labeling legislation is being reconsidered due to recent decisions by some food companies to require the labeling of all GMO products sold in their stores and to the development of GM animals for consumption [128]. Therefore, analytical methods able to detect and quantify the use of GMOs in food and feed are required in order to enforce legislation. Profiling techniques such as metabolomics and proteomics are being tested in order to identify changes in the composition of genetically engineered crops $[129,130]$. Non-targeted proteomics allows the simultaneous comparison of hundreds of plant components without the need for previous knowledge of their identity, allowing the identification of newly expressed or over-expressed proteins after the genetic modification of the organism. 2-DE has been extensively used for investigating changes between GMOs and their non-GMO isogenic varieties or non-transgenic comparators in tomato [131], wheat [132], soybean [133,134], potato [135,136], maize [137-141], and common bean [142]. Remarkably, although the DIGE technique would help improve the low inter-experimental reproducibility achieved using 2-DE approaches, it has scarcely been used for comparative studies regarding GMOs. A study using DIGE did not find alterations in protein expression caused by GM events in rice as compared with natural variation and conventional breeding [143], although a gel-free approach, using isobaric tags for relative and absolute quantitation (iTRAQ) labeling revealed differential expression between GM and wild-type rice in 103 proteins [144]. In a recent study, Mora et al. [145] reported a label-free LC-MS workflow for the relative quantification of proteins between GM and non-GM tomato varieties. Quantification was based on the intensities of the extracted ion chromatograms for the tryptic peptides matching a protein, and normalization with a spiked exogenous protein was performed to account for run-to-run variation. However, all of these are discovery studies, meaning that they focused on the identification of the differences between the GMO and the corresponding non-GMO. Further research is required on the development of methods targeting these differences for the detection and quantification of GMOs in actual food products at the low levels dictated by legislation. Although protein expression could potentially be used to differentiate GMOs from wild-type crops, permitted or licensed GMOs have well-documented insertions/deletions in their genome making detection via genomic 
approaches more specific. The current targeted genetic approaches are both faster and more cost-effective than the proteomic methods investigated to date.

\subsubsection{Other Foodstuffs}

Classical protein electrophoretic techniques have been used for the authentication of other food commodities, such as legumes and ginseng herbs. IEF followed by chemometric data analysis was able to differentiate between four dry bean cultivars [146]. Yeh et al. [147] used a simple SDS-PAGE protocol to demonstrate differences in some proteins between Oriental and American ginseng that can be useful for the differentiation of the two varieties.

MALDI-TOF protein profiling was used for the determination of the geographic origin of honey from Hawaiian bees [148]. Several samples of Hawaiian origin $(n=16)$ were used as the references for building a database library of protein mass spectra barcodes, and 38 commercial samples, including 15 labeled Hawaiian origin, were used to test the method. Four non-Hawaiian commercial samples yielded a correlation coefficient in the same range as the Hawaiian-origin ones. However, principal component analysis of protein fingerprints segregated honeys depending on the geographic origin, and those from Hawaii were clustered together. An attempt to classify honey varieties (chestnut, acacia, sunflower, eucalyptus, and orange) combining CPLL enrichment and 2-DE analysis was unsuccessful since no plant proteins were identified [149].

Zhang et al. [150] identified differential peptides for bovine and porcine gelatins using LC-MS/MS after tryptic digestion, although future experiments should be done using gelatins from different geographic areas. Since protein modifications such as proline hydroxylation can interfere with peptide identification, the product ion data obtained should be verified for correct identification, making the method less amenable to automation.

\subsection{FUTURE TRENDS}

Although the use of protein/peptide biomarkers by means of proteomic technologies is still limited in assessing food authenticity as compared to other well-established methodologies such as immunoassays or DNA-based analysis, it represents a promising alternative because of its robustness, sensitivity, multiplexing capacity, and high-throughput and discriminating power. As in DNA-based analyses, when using PFF-based methods, discrimination is made at the sequence level, making it possible to differentiate between closely related species. Moreover, peptide-based methods can resolve one of the major drawbacks of DNA methods, which is the degradation of DNA in highly processed samples [76], because (i) marker peptides can be quite stable against processing; (ii) modifications in an amino acidic sequence due to food processing (non-enzymatic PTMs) can be monitored; and (iii) heat-stable proteins can be selected as targets. This fact should encourage researchers to develop standard proteomics-based protocols to assess food authenticity. However, in future studies, efforts to address some important considerations that are lacking in most of the studies published to date should be considered. These include the careful reporting of technical details as required by the existing standards for proteomics approach, the inclusion of a proper number of representative samples (biological replicates) and technical replicates, the use of powerful and adequate statistical 
analysis, and the development and implementation of more powerful MS equipment and bioinformatic tools. As inferred by most of the studies compiled in this review, the major problem regarding the use of proteomics for food authentication is protein extraction from complex matrices and the low concentration of target proteins; therefore, further efforts must be made at the extraction and enrichment steps in order to increase the sensitivity and reproducibility of the assays. Another limiting factor that food analysis laboratories may face is the restricted availability of reference materials, considering the wide range of possible analytes, concentration, and matrix combinations of the real samples to be analyzed [151].

Since pre-analytical factors have a large impact on the output of proteomic studies, a more detailed description of sample treatment factors such as processing and sample storage is needed. In order to increase the reproducibility of results, the standardization of the sample treatment and careful reporting of the technical details are also necessary. The use of MIAPEs should be a standard for all kinds of studies using proteomic technologies, not only for clinically related studies. Correct and complete sampling should be done to assess for changes caused by (i) food processing and (ii) intra-group variability of the specimens used in the foodstuff, such as geographic origin or population changes (intraspecies variability), season changes through the year, development status (age), physiological rhythms, or pathological conditions. Different statistical methods have to be assessed to find the best discriminators that meet the expected requirements in terms of classification and differentiation. A power analysis should be included in all analyses in order to check the validity of the study and to design future experiments.

Future improvements in high-resolution MS instruments will increase the sensitivity and specificity of assays. Targeted MS/MS acquisition methods can help to fill the gap between preliminary discovery studies and final validation experiments where complete sampling is necessary to address all the possible sources of variability. The development of validated SRM LC-MS methods, combined with the use of certified reference materials as standards, may help to provide reliable analytical results that can be comparable across different laboratories. In addition to SRM, other recently developed MS acquisition methods promise much for the future. For instance, data-independent analysis acquisition modes, such as SWATH and MSe, allow the quantitative analysis of low abundance peptides in the same run that is used for protein identification, improving the analytical coverage and merging the initial discovery and the subsequent validation steps in one platform. Finally, the development of new bioinformatic tools and the application of existing ones to food proteomes and matrices will play a key role in the implementation of integrative biology and systems biology in the food technology and nutrition areas. The scientific community should make a collaborative effort to share publicly available databases and datasets and to develop certified reference materials and standard operating procedures.

Transparency document: The transparency document associated with this chapter can be found in the online version.

\section{REFERENCES}

1. J.C. Moore, J. Spink, M. Lipp, Development and application of a database of food ingredient fraud and economically motivated adulteration from 1980 to 2010, J. Food Sci. 77(4) (2012) R118-R126.

2. J. Spink, D.C. Moyer, Defining the public health threat of food fraud, J. Food Sci. 76(9) (2011) R157-R163. 
3. European Parliament, European Council, Regulation (EC) No 178/2002 of the European Parliament and of the Council of 28 January 2002 laying down the general principles and requirements of food law, establishing the European Food Safety Authority and laying down procedures in matters of food safety, Off. J. Eur. Communities L31 (2002) 1-24.

4. European Parliament, European Council, Regulation (EC) No 1830/2003 of 22 September 2003 concerning the traceability and labelling of genetically modified organisms and the traceability of food and feed products produced from genetically modified organisms and amending Directive 2001/18/EC, Off. J. Eur. Union L268 (2003) 24-28.

5. European Parliament, European Council, Regulation (EU) No 1151/2012 of the European Parliament and of the Council of 21 November 2012 on quality schemes for agricultural products and foodstuffs, Off. J. Eur. Union L343 (2012) 1-29.

6. European Commission, Commission Implementing Regulation (EU) No 579/2012 of 29 June 2012 amending Regulation (EC) No 607/2009 laying down certain detailed rules for the implementation of Council Regulation (EC) No 479/2008 as regards protected designations of origin and geographical indications, traditional terms, labelling and presentation of certain wine sector products, Off. J. Eur. Union L171 (2012) 4-6.

7. European Parliament, European Council, Regulation (EU) No 1379/2013 of the European Parliament and of the Council of 11 December 2013 on the common organisation of the markets in fishery and aquaculture products, amending Council Regulations (EC) No 1184/2006 and (EC) No 1224/2009 and repealin, Off. J. Eur. Union L354 (2013) 1-21.

8. U.S. Food and Drug Administration, US Federal Food, Drug, and Cosmetic Act. Chapter IV: Food, 2014 (www.fda.gov/regulatory-information/federal-food-drug-a nd-cosmetic-act-fdc-act/fdc-act-chapter-iv-food [accessed November 1, 2015]).

9. European Parliament, European Parliament Resolution of 14 January 2014 on the food crisis, fraud in the food chain and the control thereof $(2013 / 2091$ (INI)). P7_TA (2014)0011, 2014 (https://eur-lex.europa.eu/legal-content/EN/ALL/?uri=CE LEX\%3A52014IP0011\%2801\%29 [accessed February, 2020]).

10. S.A. Drivelos, C.A. Georgiou, Multi-element and multi-isotope-ratio analysis to determine the geographical origin of foods in the European Union, Trends Anal. Chem. 40 (2012) 38-51.

11. I. Ortea, A. Pascoal, B. Cañas, J.M. Gallardo, J. Barros-Velázquez, P. Calo-Mata, Food authentication of commercially-relevant shrimp and prawn species: From classical methods to foodomics, Electrophoresis 33(15) (2012) 2201-2211.

12. E. Cubero-Leon, R. Peñalver, A. Maquet, Review on metabolomics for food authentication, Food Res. Int. 60 (2014) 95-107.

13. A. Pandey, M. Mann, Proteomics to study genes and genomes, Nature 405(6788) (2000) 837-846.

14. D.J.C. Pappin, P. Hojrup, A. Bleasby, Rapid identification of proteins by peptide mass fingerprinting, Curr. Biol. 3(6) (1993) 327-332.

15. J.K. Eng, A.L. McCormack, R.J. Yates III, An approach to correlate tandem mass spectral data of peptides with amino acid sequences in a protein database, J. Am. Soc. Mass Spectrom. 5(11) (1994) 976-989.

16. F.W. McLafferty, K. Breuker, M. Jin, X. Han, G. Infusini, H. Jiang, et al., Topdown MS, a powerful complement to the high capabilities of proteolysis proteomics, FEBS Journal 274(24) (2007) 6256-6268. 
17. Y. Zhao, O.N. Jensen, Modification-specific proteomics: Strategies for characterization of post-translational modifications using enrichment techniques, Proteomics 9(20) (2009) 4632-4641.

18. S. Clerens, J.E. Plowman, J.M. Dyer, Food proteomics: Mapping modifications. In: J.L. Heazlewood, C.J. Petzold (Eds.), Proteomic Applications in Biology, InTech, Rijeka, 2012.

19. M. Pischetsrieder, R. Baeuerlein, Proteome research in food science, Chem. Soc. Rev. 38(9) (2009) 2600-2608.

20. A. Panchaud, M. Affolter, P. Moreillon, M. Kussmann, Experimental and computational approaches to quantitative proteomics: Status quo and outlook, J. Proteomics 71(1) (2008) 19-33.

21. J.S. Minden, S.R. Dowd, H.E. Meyer, K. Stühler, Difference gel electrophoresis, Electrophoresis 30 Supplement 1 (2009) S156-S161.

22. S. Gallien, E. Duriez, B. Domon, Selected reaction monitoring applied to proteomics, J. Mass Spectrom. 46(3) (2011) 298-312.

23. L. Kiemer, G. Cesareni, Comparative interactomics: Comparing apples and pears?, Trends Biotechnol. 25(10) (2007) 448-454.

24. S. Serim, U. Haedke, S.H.L. Verhelst, Activity-based probes for the study of proteases: Recent advances and developments, ChemMedChem 7(7) (2012) 1146-1159.

25. P.M. Angel, R.M. Caprioli, Matrix-assisted laser desorption ionization imaging mass spectrometry: In situ molecular mapping, Biochemistry 52(22) (2013) 3818-3828.

26. C. Wu, A.L. Dill, L.S. Eberlin, R.G. Cooks, D.R. Ifa, Mass spectrometry imaging under ambient conditions, Mass Spectrom. Rev. 32 (2012) 218-243.

27. D. Martínez-Maqueda, B. Hernández-Ledesma, L. Amigo, B. Miralles, J.A. GómezRuiz, Extraction/fractionation techniques for proteins and peptides and protein digestion. In: F. Toldrá, L.M.L. Nollet (Eds.), Proteomics in Foods: Principles and Applications, Springer, New York, pp. 21-50, 2013.

28. C. Taylor, N. Paton, K. Lilley, P.-A. Binz, R. Julian, A. Jones, et al., The minimum information about a proteomics experiment (MIAPE), Nat. Biotechnol. 25(8) (2007) 887-893.

29. S. Martínez-Bartolomé, P.A. Binz, J.P. Albar, The minimal information about a proteomics experiment (MIAPE) from the proteomics standards initiative, Methods Mol. Biol. 1072 (2014) 765-780.

30. A. Cereda, A.V. Kravchuk, A. D’Amato, A. Bachi, P.G. Righetti, Proteomics of wine additives: Mining for the invisible via combinatorial peptide ligand libraries, J. Proteomics 73(9) (2010) 1732-1739.

31. E. Fasoli, A. D’Amato, A.V. Kravchuk, A. Citterio, P.G. Righetti, In-depth proteomic analysis of non-alcoholic beverages with peptide ligand libraries, J. Proteomics 74(7) (2011) 1080-1090.

32. C. Esteve, A. D’Amato, M.L. Marina, M.C. García, A. Citterio, P.G. Righetti, Identification of olive (Olea europaea) seed and pulp proteins by nLC-MS/MS via combinatorial peptide ligand libraries, J. Proteomics 75(8) (2012) 2396-2403.

33. C. Esteve, A. D’Amato, M.L. Marina, M.C. García, P.G. Righetti, Identification of avocado (Persea americana) pulp proteins by nano-LC-MS/MS via combinatorial peptide ligand libraries, Electrophoresis 33(18) (2012) 2799-2805.

34. M.J. Lerma-García, A. D’Amato, E. Fasoli, E.F. Simó-Alfonso, P.G. Righetti, According to the CPLL proteome sheriffs, not all aperitifs are created equal! Biochim. Biophys. Acta 1844 (2014) 1493-1499. 
35. C. Cilindre, E. Fasoli, A. D’Amato, G. Liger-Belair, P.G. Righetti, It's time to pop a cork on champagne's proteome!, J. Proteomics 105 (2014) 351-362.

36. T. Shi, D. Su, T. Liu, K. Tang, D.G. Camp II, W.-J. Quian, et al., Advancing the sensitivity of selected reaction monitoring-based targeted quantitative proteomics, Proteomics 12(8) (2012) 1074-1092.

37. Q. Chen, T. Liu, G. Chen, Highly efficient proteolysis accelerated by electromagnetic waves for peptide mapping, Curr. Genomics 12(6) (2011) 380-390.

38. J.L. Capelo, R. Carreira, M. Diniz, L. Fernandes, M. Galesio, C. Lodeiro, et al., Overview on modern approaches to speed up protein identification workflows relying on enzymatic cleavage and mass spectrometry-based techniques, Anal. Chim. Acta 650(2) (2009) 151-159.

39. S.J. Geromanos, J.P.C. Vissers, J.C. Silva, C.A. Dorschel, G.-Z. Li, M.V. Gorenstein, et al., The detection, correlation, and comparison of peptide precursor and product ions from data independent LC-MS with data dependent LC-MS/MS, Proteomics 9(6) (2009) 1683-1695.

40. L.C. Gillet, P. Navarro, S. Tate, H. Röst, N. Selevsek, L. Reiter, et al., Targeted data extraction of the MS/MS spectra generated by data-independent acquisition: A new concept for consistent and accurate proteome analysis, Mol. Cell. Proteomics 11(6) (2012) O111.016717.

41. A. Cifuentes, Food analysis and foodomics, J. Chromatogr. A 1216(43) (2009) 7109.

42. C. Zheng, A. Chen, System biological research on food quality for personalized nutrition and health using foodomics techniques: A review, J. Food Nutr. Res. 2(9) (2014) 608-616.

43. A. D’Alessandro, L. Zolla, A. Scaloni, The bovine milk proteome: Cherishing, nourishing and fostering molecular complexity. An interactomics and functional overview, Mol. BioSyst. 7(3) (2011) 579-597.

44. G. Picariello, G. Mamone, F. Addeo, P. Ferranti, Novel mass spectrometry-based applications of the "Omic" sciences in food technology and biotechnology, Food Technol. Biotechnol. 50 (2012) 286-305.

45. G. Mamone, G. Picariello, S. Caira, F. Addeo, P. Ferranti, Analysis of food proteins and peptides by mass spectrometry-based techniques, J. Chromatogr. A 1216(43) (2009) 7130-7142.

46. P. Minkiewicz, M. Darewicz, A. Iwaniak, J. Sokolowska, P. Starowicz, J. Bucholska, et al., Common amino acid subsequences in a universal proteome-relevance for food science, Int. J. Mol. Sci. 16(9) (2015) 20748-20773.

47. M.S. Cline, M. Smoot, E. Cerami, A. Kuchinsky, N. Landys, C. Workman, et al., Integration of biological networks and gene expression data using cytoscape, Nat. Protoc. 2(10) (2007) 2366-2382.

48. A. Nikitin, S. Egorov, N. Daraselia, I. Mazo, Pathway Studio-The analysis and navigation of molecular networks, Bioinformatics 19(16) (2003) 2155-2157.

49. M. Ashburner, C.A. Ball, J.A. Blake, D. Botstein, H. Butler, J.M. Cherry, et al., Gene ontology: Tool for the unification of biology. The Gene Ontology Consortium, Nat. Genet. 25(1) (2000) 25-29.

50. M. Kanehisa, The KEGG database, Novartis Found. Symp. 42-46 (2002) 91-103.

51. C. Alfarano, C.E. Andrade, K. Anthony, N. Bahroos, M. Bajec, K. Bantoft, et al., The biomolecular interaction network database and related tools 2005 update, Nucleic Acids Res. 33 (2005) 418-424.

52. D. Croft, G. O'Kelly, G. Wu, R. Haw, M. Gillespie, L. Matthews, et al., Reactome: A database of reactions, pathways and biological processes, Nucleic Acids Res. 39 (2011) D691-D697. 
53. European Commission, Regulation (EC) No 273/2008 of 5 March 2008 laying down detailed rules for the application of Council Regulation (EC) No 1255/1999 as regards methods for the analysis and quality evaluation of milk and milk products, Off. J. Eur. Union L88 (2008) 53-61.

54. H.K. Mayer, Milk species identification in cheese varieties using electrophoretic, chromatographic and PCR techniques, Int. Dairy J. 15(6-9) (2005) 595-604.

55. J. Špoljarić, N. Mikulec, D. Plavljanić, B. Radeljević, J. Havranek, N. Antunac, Proving the adulteration of ewe and goat cheeses with cow milk using the reference method of isoelectric focusing of $\gamma$-casein, Mljekarstvo 63 (2013) 115-121.

56. R. Cozzolino, S. Passalacqua, S. Salemi, P. Malvagna, E. Spina, D. Garozzo, Identification of adulteration in milk by matrix-assisted laser desorption/ionization time-offlight mass spectrometry, J. Mass Spectrom. 36(9) (2001) 1031-1037.

57. R. Cozzolino, S. Passalacqua, S. Salemi, D. Garozzo, Identification of adulteration in water buffalo mozzarella and in ewe cheese by using whey proteins as biomarkers and matrix-assisted laser desorption/ionization mass spectrometry, J. Mass Spectrom. 37(9) (2002) 985-991.

58. F. Di Girolamo, A. Masotti, G. Salvatori, M. Scapaticci, M. Muraca, L. Putignani, A sensitive and effective proteomic approach to identify she-donkey's and goat's milk adulteration by MALDI-TOF MS fingerprinting, Int. J. Mol. Sci. 15(8) (2014) 13697-13719.

59. M. Sassi, S. Arena, A. Scaloni, MALDI-TOF-MS platform for integrated proteomic and peptidomic profiling of milk samples allows rapid detection of food adulterations, J. Agric. Food Chem. 63(27) (2015) 6157-6171. doi:10.1021/acs. jafc. 5 b02384.

60. G. Pinto, S. Caira, M. Cuollo, O. Fierro, M.A. Nicolai, L. Chianese, et al., Lactosylated casein phosphopeptides as specific indicators of heated milks, Anal. Bioanal. Chem. 402(5) (2012) 1961-1972.

61. R.-K. Chen, L.-W. Chang, Y.-Y. Chung, M.-H. Lee, Y.-C. Ling, Quantification of cow milk adulteration in goat milk using high-performance liquid chromatography with electrospray ionization mass spectrometry, Rapid Commun. Mass Spectrom. 18(10) (2004) 1167-1171.

62. L. Müller, P. Barták, P. Bednář, I. Fryšová, J. Ševčík, K. Lemr, Capillary electrophoresis-mass spectrometry-A fast and reliable tool for the monitoring of milk adulteration, Electrophoresis 29(10) (2008) 2088-2093.

63. M. Cuollo, S. Caira, O. Fierro, G. Pinto, G. Picariello, F. Addeo, Toward milk speciation through the monitoring of casein proteotypic peptides, Rapid Commun. Mass Spectrom. 24(11) (2010) 1687-1696.

64. C.D. Calvano, C. De Ceglie, A. Monopoli, C.G. Zambonin, Detection of sheep and goat milk adulterations by direct MALDI-TOF MS analysis of milk tryptic digests, J. Mass Spectrom. 47(9) (2012) 1141-1149.

65. C. Guarino, F. Fuselli, A. La Mantia, L. Longo, A. Faberi, R.M. Marianella, Peptidomic approach, based on liquid chromatography/electrospray ionization tandem mass spectrometry, for detecting sheep's milk in goat's and cow's cheeses, Rapid Commun. Mass Spectrom. 24(6) (2010) 705-713.

66. J.H.G. Cordewener, D.M.A.M. Luykx, R. Frankhuizen, M.G. Bremer, H. Hooijerink, A.H. America, Untargeted LC-QTOF mass spectrometry method for the detection of adulterations in skimmed milk powder, J. Sep. Sci. 32(8) (2009) 1216-1223.

67. J.E. Jablonski, J.C. Moore, J.M. Harnly, Nontargeted detection of adulteration of skim milk powder with foreign proteins using UHPLC-UV, J. Agric. Food Chem. 62(22) (2014) 5198-5206. 
68. C.D. Calvano, A. Monopoli, P. Loizzo, M. Faccia, C.G. Zambonin, Proteomic approach based on MALDI-TOF MS to detect powdered milk in fresh cow's milk, J. Agric. Food Chem. 61(8) (2013) 1609-1617.

69. A.J. Taylor, R. Linforth, O. Weir, T. Hutton, B. Green, Potential of electrospray mass spectrometry for meat pigment identification, Meat Sci. 33(1) (1993) 75-83.

70. E. Ponce-Alquicira, A.J. Taylor, Extraction and ESI-CID-MS/MS analysis of myoglobins from different species, Food Chem. 69(1) (2000) 81-86.

71. M. Montowska, E. Pospiech, Myosin light chain isoforms retain their species-specific electrophoretic mobility after processing, which enables differentiation between six species: 2DE analysis of minced meat and meat products made from beef, pork and poultry, Proteomics 12(18) (2012) 2879-2889.

72. M. Montowska, E. Pospiech, Species-specific expression of various proteins in meat tissue: Proteomic analysis of raw and cooked meat and meat products made from beef, pork and selected poultry species, Food Chem. 136(3-4) (2013) 1461-1469.

73. A. Leitner, F. Castro-Rubio, M.L. Marina, W. Lindner, Identification of marker proteins for the adulteration of meat products with soybean proteins by multidimensional liquid chromatography-tandem mass spectrometry, J. Proteome Res. 5(9) (2006) 2424-2430.

74. H.H. Grundy, P. Reece, M.D. Sykes, J.A. Clough, N. Audsley, R. Stones, Screening method for the addition of bovine blood-based binding agents to food using liquid chromatography triple quadrupole mass spectrometry, Rapid Commun. Mass Spectrom. 21(18) (2007) 2919-2925.

75. H.H. Grundy, P. Reece, M.D. Sykes, J.A. Clough, N. Audsley, R. Stones, Method to screen for the addition of porcine blood-based binding products to foods using liquid chromatography/triple quadrupole mass spectrometry, Rapid Commun. Mass Spectrom. 22(12) (2008) 2006-2008.

76. M. Buckley, M. Collins, J. Thomas-Oates, J.C. Wilson, Species identification by analysis of bone collagen using matrix-assisted laser desorption/ionisation time-of-flight mass spectrometry, Rapid Commun. Mass Spectrom. 23(23) (2009) 3843-3854.

77. M.A. Sentandreu, P.D. Fraser, J. Halket, R. Patel, P.M. Bramley, A proteomic based approach for detection of chicken in meat mixes, J. Proteome Res. 9(7) (2010) 3374-3383.

78. A.J. Claydon, H.H. Grundy, A.J. Charlton, M.R. Romero, Identification of novel peptides for horse meat speciation in highly processed foodstuffs, Food Addit. Contam. A 32(10) (2015) 1718-1729.

79. C. Von Bargen, J. Dojahn, D. Waidelich, H.-U. Humpf, J. Brockmeyer, New sensitive high-performance liquid chromatography-tandem mass spectrometry method for the detection of horse and pork in Halal beef, J. Agric. Food Chem. 61(49) (2013) 11986-11994.

80. S.A. Sarah, W.N. Faradalila, M.S. Salwani, I. Amin, S.A. Karsani, A.Q. Sazili, LC-QTOF-MS identification of porcine-specific peptide in heat treated pork identifies candidate markers for meat species determination, Food Chem. 199 (2016) 157-164.

81. A. Watson, Y. Gunning, N.M. Rigby, M. Philo, E.K. Kemsley, Meat authentication via multiple reaction monitoring mass spectrometry of myoglobin peptides, Anal. Chem. 87(20) (2015) 10315-10322.

82. A. Ruiz Orduna, E. Husby, C.T. Yang, D. Ghosh, F. Beaudry, Assessment of meat authenticity using bioinformatics, targeted peptide biomarkers and high-resolution mass spectrometry, Food Addit. Contam. Part A Chem. Anal. Control Expo. 32(10) (2015) 1709-1717. 
83. K. Hollung, H. Grove, E.M. Færgestad, M.S. Sidhu, P. Berg, Comparison of muscle proteome profiles in pure breeds of Norwegian Landrace and Duroc at three different ages, Meat Sci. 81(3) (2009) 487-492.

84. Y.J. Xu, M.L. Jin, L.J. Wang, A.D. Zhang, B. Zuo, D.Q. Xu, et al., Differential proteome analysis of porcine skeletal muscles between Meishan and Large White, J. Anim. Sci. 87(8) (2009) 2519-2527.

85. A.M. Timperio, A. D’Alessandro, L. Pariset, G.M. D’Amici, A. Valentini, L. Zolla, Comparative proteomics and transcriptomics analyses of livers from two different Bos taurus breeds: "Chianina and Holstein Friesian", J. Proteomics 73(2) (2009) 309-322.

86. H. An, M.R. Marshall, W.S. Otwell, C.I. Wei, Electrophoretic identification of raw and cooked shrimp using various protein extraction systems, J. Food Sci. 53(2) (1988) 313-318.

87. H. An, M.R. Marshall, W.S. Otwell, C.I. Wei, Species identification of raw and boiled shrimp by a urea gel isoelectric focusing technique, J. Food Sci. 54(2) (1989) 233-236.

88. T. Civera, E. Parisi, The use of sodium dodecyl sulphate polyacrylamide gel electrophoresis for the identification of raw and cooked shrimps and crabs, Ital. J. Food Sci. 3 (1991) 149-157.

89. H. Rehbein, Food control by applied biochemistry of marine organisms: Comparison of proteins and metabolites from fish and invertebrate muscle, Helgoländer Meeresun. 49(1-4) (1995) 747-757.

90. I. Ortea, B. Cañas, P. Calo-Mata, J. Barros-Velázquez, J.M. Gallardo, Identification of commercial prawn and shrimp species of food interest by native isoelectric focusing, Food Chem. 121(2) (2010) 569-574.

91. K. Shiomi, Y. Sato, S. Hamamoto, H. Mita, K. Shimakura, Sarcoplasmic calciumbinding protein: Identification as a new allergen of the black tiger shrimp Penaeus monodon, Int. Arch. Allergy Immunol. 146(2) (2008) 91-98.

92. J.L. López, A. Marina, J. Vázquez, G. Álvarez, A proteomic approach to the study of the marine mussels Mytilus edulis and M. galloprovincialis, Mar. Biol. 141(2) (2002) 217-223.

93. J.L. López, A. Marina, G. Álvarez, J. Vázquez, Application of proteomics for fast identification of species-specific peptides from marine species, Proteomics 2(12) (2002) 1658-1665.

94. S. Artigaud, R. Lavaud, J. Thébault, F. Jean, Ø. Strand, T. Strohmeier, et al., Proteomic based comparison between populations of the great scallop, Pecten maximus, J. Proteomics 105 (2014) 164-173.

95. I. Ortea, B. Cañas, P. Calo-Mata, J. Barros-Velázquez, J.M. Gallardo, Arginine kinase peptide mass fingerprinting as a proteomic approach for species identification and taxonomic analysis of commercially relevant shrimp species, J. Agric. Food Chem. 57(13) (2009) 5665-5672.

96. I. Ortea, B. Cañas, J.M. Gallardo, Mass spectrometry characterization of speciesspecific peptides from arginine kinase for the identification of commercially relevant shrimp species, J. Proteome Res. 8(11) (2009) 5356-5362.

97. A. Pascoal, I. Ortea, J.M. Gallardo, B. Cañas, J. Barros-Velázquez, P. Calo-Mata, Species identification of the northern shrimp (Pandalus borealis) by polymerase chain reaction-restriction fragment length polymorphism and proteomic analysis, Anal. Biochem. 421(1) (2012) 56-67.

98. I. Ortea, B. Cañas, J.M. Gallardo, Selected tandem mass spectrometry ion monitoring for the fast identification of seafood species, J. Chromatogr. A 1218(28) (2011) $4445-4451$. 
99. V. Salla, K.K. Murray, Matrix-assisted laser desorption ionization mass spectrometry for identification of shrimp, Anal. Chim. Acta 794 (2013) 55-59.

100. M. Etienne, M. Jérome, J. Fleurence, H. Rehbein, R. Kündiger, R. Mendes, et al., Identification of fish species after cooking by SDS-PAGE and urea IEF: A collaborative study, J. Agric. Food Chem. 48(7) (2000) 2653-2658.

101. P. Bossier, K. Cooreman, A databank able to be used for identifying and authenticating commercial flatfish (Pleuronectiformes) products at the species level using isoelectric focusing of native muscle proteins, Int. J. Food Sci. Technol. 35(6) (2000) 563-568.

102. P. Renon, C. Bernardi, R. Malandra, P.A. Biondi, Isoelectric focusing of sarcoplasmic proteins to distinguish swordfish, blue marlin and Mediterranean spearfish, Food Control 16(5) (2005) 473-477.

103. C. Piñeiro, J. Barros-Velázquez, C.G. Sotelo, R.I. Pérez-Martín, J.M. Gallardo, Two-dimensional electrophoretic study of the water-soluble protein fraction in white muscle of gadoid fish species, J. Agric. Food Chem. 46(10) (1998) 3991-3997.

104. C. Piñeiro, J. Barros-Velázquez, C.G. Sotelo, J.M. Gallardo, The use of two-dimensional electrophoresis in the characterization of the water-soluble protein fraction of commercial flat fish species, Zeitschrift Für Leb. Und-Forsch. A 208 (1999) $342-348$.

105. C. Piñeiro, J. Vázquez, A. Marina, J. Barros-Velázquez, J.M. Gallardo, Characterization and partial sequencing of species-specific sarcoplasmic polypeptides from commercial hake species by mass spectrometry following two-dimensional electrophoresis, Electrophoresis 22(8) (2001) 1545-1552.

106. T. Pepe, M. Ceruso, A. Carpentieri, I. Ventrone, A. Amoresano, A. Anastasio, Proteomics analysis for the identification of three species of Thunnus, Vet. Res. Commun. 34 Supplement 1 (2010) S153-S155.

107. T. Pepe, M. Ceruso, A. Carpentieri, I. Ventrone, A. Amoresano, A. Anastasio, et al., Differentiation of four tuna species by two-dimensional electrophoresis and mass spectrometric analysis. In: J.L. Heazlewood, C.J. Petzold (Eds.), Proteomic Applications in Biology, InTech, Rijeka, 2012.

108. I. Martinez, T.J. Friis, Application of proteome analysis to seafood authentication, Proteomics 4(2) (2004) 347-354.

109. T.-Y. Chen, C.-Y. Shiau, C.-I. Wei, D.-F. Hwang, Preliminary study on puffer fish proteome-species identification of puffer fish by two-dimensional electrophoresis, J. Agric. Food Chem. 52(8) (2004) 2236-2241.

110. I. Martínez, R. Slizyte, E. Dauksas, High resolution two-dimensional electrophoresis as a tool to differentiate wild from farmed cod (Gadus morhua) and to assess the protein composition of klipfish, Food Chem. 102(2) (2007) 504-510.

111. S.K. Barik, S. Banerjee, S. Bhattacharjee, S.K. Das Gupta, S. Mohanty, et al., Proteomic analysis of sarcoplasmic peptides of two related fish species for food authentication, Appl. Biochem. Biotechnol. 171(4) (2013) 1011-1021.

112. M. Carrera, B. Cañas, P. Piñeiro, J. Vázquez, J.M. Gallardo, Identification of commercial hake and grenadier species by proteomic analysis of the parvalbumins fraction, Proteomics 6(19) (2006) 5278-5287.

113. M. Carrera, B. Cañas, D. López-Ferrer, C. Piñeiro, J. Vázquez, J.M. Gallardo, Fast monitoring of species-specific peptide biomarkers using high-intensity-focus ed-ultrasound-assisted tryptic digestion and selected MS/MS ion monitoring, Anal. Chem. 83(14) (2011) 5688-5695. 
114. M. Carrera, B. Cañas, C. Piñeiro, J. Vázquez, J.M. Gallardo, De novo mass spectrometry sequencing and characterization of species-specific peptides from nucleoside diphosphate kinase B for the classification of commercial fish species belonging to the family Merlucciidae, J. Proteome Res. 6(8) (2007) 3070-3080.

115. M.F. Mazzeo, B. de Giulio, G. Guerriero, G. Ciarcia, A. Malorni, G.L. Russo, et al., Fish authentication by MALDI-TOF mass spectrometry, J. Agric. Food Chem. 56(23) (2008) 11071-11076.

116. T. Wulff, M.E. Nielsen, A.M. Deelder, F. Jessen, M. Palmblad, Authentication of fish products by large-scale comparison of tandem mass spectra, J. Proteome Res. 12(11) (2013) 5253-5259.

117. P.G. Righetti, A. D’Amato, E. Fasoli, E. Boschetti, In Taberna quando sumus: A drunkard's cakewalk through wine proteomics, Food Technol. Biotechnol. 50 (2012) 253-260.

118. F. Di Girolamo, G.P. Righetti, M. Soste, Y. Feng, P. Picotti, Reproducibility of combinatorial peptide ligand libraries for proteome capture evaluated by selected reaction monitoring, J. Proteomics 89 (2013) 215-226.

119. A. Chambery, G. del Monaco, A. Di Maro, A. Parente, Peptide fingerprint of high quality Campania white wines by MALDI-TOF mass spectrometry, Food Chem. 113(4) (2009) 1283-1289.

120. D. Resetar, M. Marchetti-Deschmann, G. Allmaier, J.P. Katalinic, S. Kraljevic, Matrix assisted laser desorption ionization mass spectrometry linear time-of-flight method for white wine fingerprinting and classification, Food Control 64 (2016) 157-164.

121. European Council, Council Regulation (EC) No 1234/2007 of 22 October 2007 establishing a common organisation of agricultural markets and on specific provisions for certain agricultural products (Single CMO Regulation), Off. J. Eur. Union L299 (2007) 1-149.

122. A. D’Amato, A.V. Kravchuk, A. Bachi, P.G. Righetti, Noah's nectar: The proteome content of a glass of red wine, J. Proteomics 73(12) (2010) 2370-2377.

123. A. Cryar, C. Pritchard, W. Burkitt, M. Walker, G. O’Connor, M. Quaglia, A mass spectrometry-based reference method for the analysis of lysozyme in wine and the production of certified reference materials, J. Assoc. Public Anal. 40 (2012) 77-80.

124. L. Monaci, I. Losito, F. Palmisano, A. Visconti, Identification of allergenic milk proteins markers in fined white wines by capillary liquid chromatography-electrospray ionization-tandem mass spectrometry, J. Chromatogr. A 1217(26) (2010) 4300-4305.

125. L. Monaci, I. Losito, F. Palmisano, A. Visconti, Reliable detection of milk allergens in food using a high-resolution, stand-alone mass spectrometer, J. AOAC Int. 94(4) (2011) 1034-1042.

126. L. Monaci, I. Losito, E. De Angelis, R. Pilolli, A. Visconti, Multi-allergen quantification of fining-related egg and milk proteins in white wines by high-resolution mass spectrometry, Rapid Commun. Mass Spectrom. 27(17) (2013) 2009-2018.

127. G.P. Gruere, S.R. Rao, A review of international labeling policies of genetically modified food to evaluate India's proposed rule, AgBioforum 10 (2007) 51-64.

128. A.E. Wohlers, Labeling of genetically modified food: Closer to reality in the United States?, Pol. Life Sci. 32(1) (2013) 73-84.

129. V. García-Cañas, C. Simó, C. León, E. Ibáñez, A. Cifuentes, MS-based analytical methodologies to characterize genetically modified crops, Mass Spectrom. Rev. 30(3) (2011) 396-416. 
130. A. Valdés, C. Simó, C. Ibáñez, V. García-cañas, Foodomics strategies for the analysis of transgenic foods, Trends Anal. Chem. 52 (2013) 2-15.

131. D. Corpillo, G. Gardini, A.M. Vaira, M. Basso, S. Aime, G.P. Accotto, et al., Proteomics as a tool to improve investigation of substantial equivalence in genetically modified organisms: The case of a virus-resistant tomato, Proteomics 4(1) (2004) 193-200.

132. F. Scossa, D. Laudencia-Chingcuanco, O.D. Anderson, W.H. Vensel, D. Lafiandra, R. D'Ovidio, et al., Comparative proteomic and transcriptional profiling of a bread wheat cultivar and its derived transgenic line overexpressing a low molecular weight glutenin subunit gene in the endosperm, Proteomics 8(14) (2008) 2948-2966.

133. A.R. Brandão, H.S. Barbosa, M.A. Arruda, Image analysis of two-dimensional gel electrophoresis for comparative proteomics of transgenic and non-transgenic soybean seeds, J. Proteomics 73(8) (2010) 1433-1440.

134. H.S. Barbosa, S.C. Arruda, R.A. Azevedo, M.A. Arruda, New insights on proteomics of transgenic soybean seeds: Evaluation of differential expression of enzymes and proteins, Anal. Bioanal. Chem. 402(1) (2012) 299-314.

135. C. Goulet, M. Benchabane, R. Anguenot, F. Brunelle, M. Khalf, D. Michaud, A companion protease inhibitor for the protection of cytosol-targeted recombinant proteins in plants, Plant Biotechnol. J. 8(2) (2010) 142-154.

136. M. Khalf, C. Goulet, J. Vorster, F. Brunelle, R. Anguenot, I. Fliss, et al., Tubers from potato lines expressing a tomato Kunitz protease inhibitor are substantially equivalent to parental and transgenic controls, Plant Biotechnol. J. 8(2) (2010) 155-169.

137. L. Zolla, S. Rinalducci, P. Antonioli, P.G. Righetti, Proteomics as a complementary tool for identifying unintended side effects occurring in transgenic maize seeds as a result of genetic modifications, J. Proteome Res. 7(5) (2008) 1850-1861.

138. E. Barros, S. Lezar, M.J. Anttonen, J.P. Van Dijk, R.M. Röhlig, E.J. Kok, et al., Comparison of two GM maize varieties with a near-isogenic non-GM variety using transcriptomics, proteomics and metabolomics, Plant Biotechnol. J. 8(4) (2010) 436-451.

139. G.M. Balsamo, G.C. Cangahuala-Inocente, J.B. Bertoldo, H. Terenzi, A.C. Arisi, Proteomic analysis of four Brazilian MON810 maize varieties and their four non-genetically-modified isogenic varieties, J. Agric. Food Chem. 59(21) (2011) 11553-11559.

140. A. Coll, A. Nadal, M. Rossignol, P. Puigdomènech, M. Pla, Proteomic analysis of MON810 and comparable non-GM maize varieties grown in agricultural fields, Transgen. Res. 20(4) (2011) 939-949.

141. S.Z. Agapito-Tenfen, M.P. Guerra, O.G. Wikmark, R.O. Nodari, Comparative proteomic analysis of genetically modified maize grown under different agroecosystems conditions in Brazil, Proteome Sci. 11(1) (2013) 46.

142. G.M. Balsamo, P.A. Valentim-Neto, C.S. Mello, A.C.M. Arisi, Comparative proteomic analysis of two varieties of genetically modified (GM) Embrapa 5.1 common bean (Phaseolus vulgaris L.) and their non-GM counterparts, J. Agric. Food Chem. 63 (2015) 10569-10577.

143. C.Y. Gong, Q. Li, H.T. Yu, Z. Wang, T. Wang, Proteomics insight into the biological safety of transgenic modification of rice as compared with conventional genetic breeding and spontaneous genotypic variation, J. Proteome Res. 11(5) (2012) 3019-3029. 
144. J. Luo, T. Ning, Y. Sun, J. Zhu, Y. Zhu, Q. Lin, et al., Proteomic analysis of rice endosperm cells in response to expression of hGM-CSF, J. Proteome Res. 8(2) (2009) 829-837.

145. L. Mora, P.M. Bramley, P.D. Fraser, Development and optimisation of a label-free quantitative proteomic procedure and its application in the assessment of genetically modified tomato fruit, Proteomics 13(12-13) (2013) 2016-2030.

146. R.M. Ruiz, R. Ortiz, P. Álvarez, Dry bean cultivar characterisation by isoelectric focusing electrophoresis in polyacrylamide gel, J. Sci. Food Agric. 81(11) (2001) 1126-1131.

147. J.M. Yeh, J.W.-Y. Ong, K.Y.-L. Yap, Proteomic analysis of ginseng, ICBPE 2006Proc. Int. Conf. Biomed. Pharm. Eng, pp. 459-460, 2006. Wiley-Blackwell Southern Gate, Chichester, U.K.

148. J. Wang, M.M. Kliks, W. Qu, S. Jun, G. Shi, Q.X. Li, Rapid determination of the geographical origin of honey based on protein fingerprinting and barcoding using MALDI-TOF MS, J. Agric. Food Chem. 57(21) (2009) 10081-10088.

149. F. Di Girolamo, A. D’Amato, P.G. Righetti, Assessment of the floral origin of honey via proteomic tools, J. Proteomics 75(12) (2012) 3688-3693.

150. G.F. Zhang, T. Liu, Q. Wang, L. Chen, J.D. Lei, J. Luo, et al., Mass spectrometric detection of marker peptides in tryptic digests of gelatin: A new method to differentiate between bovine and porcine gelatin, Food Hydrocoll. 23(7) (2009) 2001-2007.

151. H. Emons, A. Held, F. Ulberth, Reference materials as crucial tools for quality assurance and control in food analysis, Pure Appl. Chem. 78(1) (2006) 135-143. 
$\bigoplus$ Taylor \& Francis 